\title{
Dimethyl sulfide dynamics in first-year sea ice melt ponds in the Canadian Arctic Archipelago
}

\author{
Margaux Gourdal ${ }^{1}$, Martine Lizotte ${ }^{1}$, Guillaume Massé ${ }^{1}$, Michel Gosselin $^{2}$, Michel Poulin $^{3}$, Michael Scarratt $^{4}$, \\ Joannie Charette ${ }^{2}$, and Maurice Levasseur ${ }^{1}$ \\ ${ }^{1}$ Département de biologie, Québec-Océan and Unité Mixte Internationale 3376 TAKUVIK, CNRS-Université Laval, \\ 1045 Avenue de la Médecine, Ville de Québec, Québec G1V 0A6, Canada \\ ${ }^{2}$ Institut des Sciences de la Mer de Rimouski (ISMER), Université du Québec à Rimouski, 310 Allée des Ursulines, \\ Rimouski, Québec G5L 3A1, Canada \\ ${ }^{3}$ Research and Collections, Canadian Museum of Nature, P.O. Box 3443, Station D, Ottawa, Ontario K1P 6P4, Canada \\ ${ }^{4}$ Maurice Lamontagne Institute, Fisheries and Oceans Canada, P.O. Box 1000, Mont-Joli, Québec G5H 3Z4, Canada
}

Correspondence: Margaux Gourdal (margaux.gourdal@takuvik.ulaval.ca)

Received: 15 October 2017 - Discussion started: 21 November 2017

Revised: 4 April 2018 - Accepted: 7 May 2018 - Published: 29 May 2018

\begin{abstract}
Melt pond formation is a seasonal pan-Arctic process. During the thawing season, melt ponds may cover up to $90 \%$ of the Arctic first-year sea ice (FYI) and 15 to $25 \%$ of the multi-year sea ice (MYI). These pools of water lying at the surface of the sea ice cover are habitats for microorganisms and represent a potential source of the biogenic gas dimethyl sulfide (DMS) for the atmosphere. Here we report on the concentrations and dynamics of DMS in nine melt ponds sampled in July 2014 in the Canadian Arctic Archipelago. DMS concentrations were under the detection limit $\left(<0.01 \mathrm{nmol} \mathrm{L}^{-1}\right)$ in freshwater melt ponds and increased linearly with salinity $\left(r_{\mathrm{s}}=0.84, p \leq 0.05\right)$ from $\sim 3$ up to $\sim 6 \mathrm{nmol} \mathrm{L}^{-1}$ (avg. $\left.3.7 \pm 1.6 \mathrm{nmol} \mathrm{L}^{-1}\right)$ in brackish melt ponds. This relationship suggests that the intrusion of seawater in melt ponds is a key physical mechanism responsible for the presence of DMS. Experiments were conducted with water from three melt ponds incubated for $24 \mathrm{~h}$ with and without the addition of two stable isotope-labelled precursors of DMS (dimethylsulfoniopropionate), (D6-DMSP) and dimethylsulfoxide $\left({ }^{13} \mathrm{C}\right.$-DMSO). Results show that de novo biological production of DMS can take place within brackish melt ponds through bacterial DMSP uptake and cleavage. Our data suggest that FYI melt ponds could represent a reservoir of DMS available for potential flux to the atmosphere. The importance of this ice-related source of DMS for the Arctic atmosphere is expected to increase as a response to the thinning of sea ice and the areal and temporal expansion of melt ponds on Arctic FYI.
\end{abstract}

\section{Introduction}

Melt ponds represent an important but understudied component of the Arctic sea ice system. Snow deposited at the surface of the sea ice progressively melts during the thawing season and may accumulate above sea level in depressions at the surface of the ice to form melt ponds (Lüthje et al., 2006), likely through a recently identified process of percolation blockage (Polashenski et al., 2017). In the Arctic, melt pond fraction over first-year sea ice (FYI) in late springsummer usually ranges from 50 to $60 \%$, locally reaching $90 \%$ (Fetterer and Untersteiner, 1998; Eicken et al., 2004; Lüthje et al., 2006; Perovich et al., 2011). Rösel et al. (2012) reported a $15 \%$ increase of the relative melt pond fraction for the month of June during the last decade (2001-2011) in the Arctic, most likely attributable to global climate change. This partly reflects the progressive replacement of multi-year sea ice (MYI) by FYI observed since the 1980s (National Snow and Ice Data Center, NSIDC, http://nsidc.org, last access: June 2017), favouring the formation of shallow melt ponds that spread over increasingly large areas (Agarwal et al., 2011; Ehn et al., 2011). The importance of melt ponds in the Arctic, as a water-air interface involved in heat and gas exchanges, is thus expected to increase in the future.

Dimethyl sulfide (DMS) is the main natural source of reduced sulfur for the atmosphere (Bates et al., 1992). Between 17.6 and $34.4 \mathrm{Tg}$ of sulfur is released annually from the ocean to the atmosphere (Lana et al., 2011), accounting 
for $50-60 \%$ of the natural reduced sulfur emitted (Stefels et al., 2007). DMS is also a climate-relevant gas potentially involved in a feedback loop known as the CLAW hypothesis (Charlson et al., 1987) linking biology and climate through the production of DMS-derived sulfate aerosols. According to CLAW, DMS emissions may affect the global radiation budget directly through the scattering of incoming solar radiation and indirectly via the production of cloud condensation nuclei $(\mathrm{CCN})$, leading to the genesis of longer-lived clouds with higher albedo (Twomey, 1974; Albrecht, 1989). Inspiring three decades of research and hundreds of publications, the feedback mechanism proposed by Charlson et al. (1987) remains to be demonstrated in its entirety (e.g. Ayers and Cainey, 2008). Although modelling results show that DMS emissions may have a negative radiative effect (e.g. Bopp et al., 2004; Gunson et al., 2006; Thomas et al., 2010), CCN may exhibit a low sensitivity to changes in DMS on a global scale (Woodhouse et al., 2010). Recent studies questioning the relative importance of DMS in new particle formation have emerged, suggesting that the global CLAW feedback may be weak (e.g. Quinn and Bates, 2011; Green and Hatton, 2014). On a regional scale, however, the response of $\mathrm{CCN}$ production to change in DMS may vary by a factor of 20 (Woodhouse et al., 2010). The impact of DMS emissions on cloud properties (through the production of $\mathrm{CCN}$ ) could be particularly important in remote pristine marine areas such as the polar regions (Carslaw et al., 2013). In the Southern Ocean, DMS may have contributed up to $33 \%$ of the increase in CCN observed south of $65^{\circ} \mathrm{S}$ as a response of increased wind speed since the early 1980s (Korhonen et al., 2010). The summertime Arctic marine boundary layer (MBL) is left relatively clean after seasonal wet deposition of particles and reduced atmospheric transport of aerosols from anthropogenic sources at lower latitudes (Stohl, 2006; Browse et al., 2012; Croft et al., 2016). Such pristine conditions, combined with thermally stable MBL, are typical of the Arctic summertime (e.g. Aliabadi et al., 2016). Clean Arctic air masses allow ultrafine (5-20 nm diameter) particle formation (Burkart et al., 2017) and the potential growth of secondary marine organic aerosols (including DMS-derived particles) into CCN (Willis et al., 2016). Hence, the Arctic is a favourable terrain for new particle formation from biogenic DMS (Chang et al., 2011; Rempillo et al., 2011; Collins et al., 2017; Giamarelou et al., 2016; Mungall et al., 2016; Willis et al., 2016).

DMS stems mainly from the enzymatic cleavage of dimethylsulfoniopropionate (DMSP) by algal and bacterial DMSP lyases. DMSP is a cellular metabolite found in several phytoplankton species as particulate DMSP $\left(\mathrm{DMSP}_{\mathrm{p}}\right.$ ) (see the review of Green and Hatton, 2014). DMSP $p$ plays various roles in phytoplankton, including osmoregulation (Lyon et al., 2016), cryoprotection (Karsten et al., 1996), and prevention of cellular oxidation (Sunda et al., 2002). Part of the DMSP $_{p}$ produced by algae is released in the water column as dissolved DMSP $\left(\right.$ DMSP $\left._{d}\right)$ via several pathways reviewed in Stefels et al. (2007), including active exudation, cell lysis, viral lysis, and zooplankton grazing. $\mathrm{DMSP}_{\mathrm{d}}$ is then readily available to heterotrophic bacteria as carbon and sulfur sources (Kiene et al., 2000; Simó, 2001; Vila-Costa et al., 2006). The fraction of $\mathrm{DMSP}_{\mathrm{d}}$ consumed by heterotrophic bacteria and enzymatically cleaved by DMSP lyases into DMS (DMS yield) may vary depending on the composition of microbial communities, their sulfur requirements, and the availability of other reduced forms of sulfur (Kiene et al., 2000; Stefels et al., 2007). DMSP lyases are also present in several members of the microalgal groups Haptophyceae and Dinophyceae and, to a lesser extent, Chrysophyceae (Niki et al., 2000). Ultimately, between $\sim 1$ and $40 \%$ of the DMSP produced by algae reaches the atmosphere as DMS (Stefels et al., 2007; Simó and Pedros-Alio, 1999a). In addition to the DMSP enzymatic cleavage pathway, DMS production may arise from dimethylsulfoxide (DMSO) reduction by various groups of marine bacteria including proteobacteria (e.g. Vogt et al., 1997), members of the Roseobacter group (González et al., 1999), and mat-forming cyanobacteria (van Bergeijk and Stal, 1996). However, the ubiquity of this DMSO-to-DMS reduction pathway amongst bacterial assemblages has not been established (Hatton et al., 2012). A limited number of phytoplankton species could also be involved in the reduction of DMSO into DMS (e.g. Fuse et al., 1995; Spiese et al., 2009). Increasing evidence suggests that particulate DMSO $\left(\mathrm{DMSO}_{\mathrm{p}}\right)$ may be directly synthesized by a potentially wide range of marine phytoplankton and could be involved in osmoprotection, cryoprotection (Lee and de Mora, 1999), and antioxidant protective mechanisms (Sunda et al., 2002). As for dissolved DMSO $\left(\mathrm{DMSO}_{\mathrm{d}}\right)$, it is ubiquitous in seawater and continuous improvements in analytical techniques suggest that $\mathrm{DMSO}_{\mathrm{d}}$ may be as abundant as DMS in surface waters (e.g. Simó et al., 2000). DMSO is also a known sink for DMS (Hatton et al., 2004) via bacterial and photo-oxidation of DMS to DMSO. Vertical mixing and ventilation are also major removal processes influencing DMS concentrations in surface mixed layers (Bates et al., 1994; Kieber et al., 1996; Simó and Pedrós-Alió, 1999b; del Valle et al., 2007, 2009).

Ice-associated environments such as bottom sea ice, brine channels, melt ponds, under-ice surface waters, and leads provide complex and dynamic habitats to diverse microorganism communities involved in sulfur cycling (Levasseur, 2013). In the Arctic, the highest microalgal biomasses are found in the bottom $\sim 0.1 \mathrm{~m}$ of sea ice, with chlorophyll $a$ (Chl a) concentrations several orders of magnitude above values for under-ice waters values (e.g. Legendre et al., 1992). A similar pattern of DMSP, DMSO and DMS buildup in bottom ice has been reported both in the Arctic and Antarctica (Kirst et al., 1991; Levasseur et al., 1994; Turner et al., 1995; DiTullio and Smith Jr., 1995; Lee et al., 2001; Trevena et al., 2003; Trevena and Jones, 2006; Delille et al., 2007; Tison et al., 2010; Asher et al., 2011; Nomura et al., 2012; Galindo et al., 2015). For example, $\mathrm{DMSP}_{\mathrm{p}}$ concentrations up to $15000 \mathrm{nmol} \mathrm{L}^{-1}$ have been documented during spring in bottom FYI of the eastern Arctic (Galindo et 
al., 2014) while surface water concentrations generally range between $1 \pm 0.2$ and $50 \mathrm{nmol} \mathrm{L}^{-1}$ (Vila-Costa et al., 2008; Matrai and Vernet, 1997). DMSP, DMSO, and DMS are also present throughout the ice column within the brine network (Levasseur et al., 1994; Trevena and Jones, 2006; Asher et al., 2011). Given that primary producers are the sole source of DMSP, very high ice concentrations of $\mathrm{Chl} a$ can be correlated with DMSP through a first-order relationship (Levasseur, 2013). This Chl $a$ to DMSP relationship may not hold for lower biomass concentrations (Tison et al., 2010). In addition to the variability induced by inter-specific differences in DMSP cellular contents (e.g. Keller et al., 1989; Stefels, 2000), environmental forcing are known to control DMSP, DMSO, and DMS concentrations. In ice-associated environments, brine volume fraction might also be key in explaining DMS cycling variability via the control of ice permeability (Carnat et al., 2014). Structural changes within sea ice during the melt season, namely increases in brine volume fraction and ice desalination, result in increased connectivity and permeability in the warming sea ice (Willis et al., 2016; Polashenski et al., 2012) and influence DMSP and DMS cycling (Tison et al., 2010; Carnat et al., 2014). Also, phytoplankton blooms developing under the ice during the melting period have been shown to produce large quantities of $\mathrm{DMSP}_{\mathrm{p}}$, potentially leading to a build-up of DMS concentrations (Levasseur et al., 1994). In spite of the spatial importance of melt ponds, only a few studies have investigated their role as a source of DMS for the Arctic atmosphere (e.g. Levasseur, 2013).

Considerable efforts have been dedicated to the understanding of underlying process controlling the physics of melt ponds and their feedbacks on climate through the control of surface energy balance of the ice (Lüthje et al., 2006; Polashenski et al., 2017). However, little is known about their biogeochemistry. Four studies have specifically reported on DMS in melt ponds so far. They reveal negligible DMS concentrations in MYI ice melt ponds in the central Arctic Ocean and concentrations up to $2.2 \mathrm{nmol} \mathrm{L}^{-1}$ in the High Arctic (Leck and Persson, 1996; Sharma et al., 1999). In Antarctica, DMS concentrations ranging between 1.1 and $3.7 \mathrm{nmol} \mathrm{L}^{-1}$ and between below the detection limit (d.1.) and $250 \mathrm{nmol} \mathrm{L}^{-1}$ were measured in two studies (Nomura et al., 2012, and Asher et al., 2011, respectively). In the latter study, bacterial DMSO reduction was suggested as a possible mechanism responsible for the high DMS concentrations observed although no actual rates of DMS production, either from DMSO or DMSP, were measured. High DMS concentrations reported in the Antarctic are most likely related to the development of a surface ice community following flooding, a process whereby heavy snow load pushes the ice below the water level. Flooding is common in the Antarctic and results in the formation of snow ice (Hunke et al., 2011). Several studies document melt pond colonization by micro-, nano-, and picosized algae as well as bacteria (Bursa, 1963; Gradinger et al., 2005; Elliott et al., 2015), suggesting that DMS in melt ponds may originate from algal and bacterial metabolism. However, in situ DMS production had never been measured nor had key mechanisms been identified. Here, we report on the DMS concentrations in nine melt ponds located in the eastern Canadian Arctic Archipelago (CAA) and on the prerequisites and processes responsible for the presence of this climateactive gas. This is the first attempt to assess the dynamics of DMS in Arctic melt ponds. We identified sea ice permeability as a major control of DMS production in melt ponds, mediating the transport of both DMS and DMS-producing communities toward the surface of sea ice. We also provide the first evidence for direct in situ DMS production in Arctic melt ponds. We propose that seasonally melting sea ice might become increasingly prone to DMS production as FYI become largely predominant on the regional scale.

\section{Materials and methods}

\subsection{Study sites and environmental measurements}

Nine melt ponds distributed between four stations located in Navy Board Inlet (Ice1-MP1 and MP2-18 July), Barrow Strait (Ice2-MP1 to MP3-20 July and Ice3-MP1 and MP2-21 July), and Resolute Passage (Ice4-MP1 and MP223 July) were sampled during the joint NETCARE/ArcticNet research cruise conducted in 2014 on board the Canadian Coast Guard Ship (CCGS) Amundsen (Fig. 1).

At each station except for Ice2 (logistical constraints associated with ship time line), measurements of sea ice thickness, snow depth, and sea ice freeboard (the height of sea ice above the ocean surface) were conducted within a $3 \mathrm{~m}$ distance of the melt ponds using a gauge (Kovacs Enterprise, Roseburg, OR, USA) (Table 1). The $3 \mathrm{~m}$ distance was a compromise between maximizing the proximity of ice and melt pond samples and minimizing melt pond disturbance during sampling operations. Ice and freeboard thickness presented in Table 1 are averaged values of the seven (Ice1) to eight (Ice3 and Ice4) ice cores sampled at each station between the team members for their respective projects. In order to estimate the permeability of the ponded ice, sea ice temperature and bulk salinity were measured following Miller et al. (2015) at stations Ice1, Ice3, and Ice4. Two ice cores for sea ice temperature and salinity measurements were extracted using a $0.09 \mathrm{~m}$ core barrel (Kovacs Mark II, Kovacs Enterprise, Roseburg, OR, USA). In situ sea ice temperature profiles were measured directly, at $0.1 \mathrm{~m}$ intervals, using a high-precision thermometer (Testo ${ }^{\circledR} 720$; precision of $\pm 0.1^{\circ} \mathrm{C}$ ). Corresponding sea ice salinity profiles were also determined at $0.1 \mathrm{~m}$ intervals. Each $0.1 \mathrm{~m}$ section was cut with a handsaw, stored in a plastic container, and allowed to melt at room temperature. Bulk salinity of the melted ice section was determined using a conductivity probe (Cond $330 \mathrm{i}, \mathrm{WTW}^{\mathrm{TM}}$; precision of $\pm 0.1 \%$ ). Permeability to fluid transport was assessed with brine volume profile calcula- 

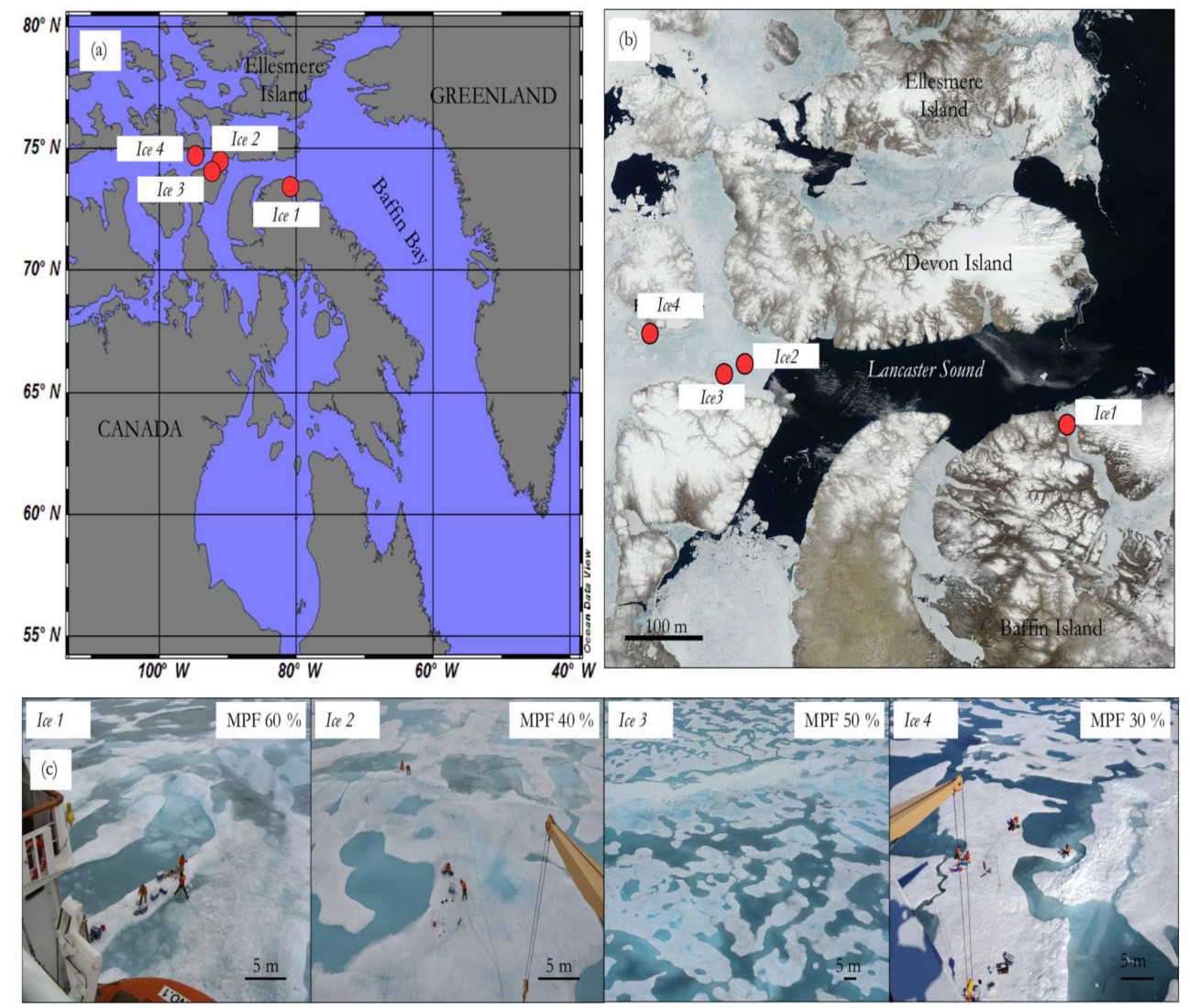

Figure 1. (a) Regional map showing the location of the four sampling stations (Ice1 to Ice4) (red circles) during the NETCARE/ArcticNet 2014 campaign. (b) MODIS imagery above the four sampling station (red circles) showing the ice conditions on 18 July 2014 in the sampling area. (c) Left to right, pictures of stations Ice1, Ice2, Ice3 and Ice4 with size scale. MPF stands for the melt pond fraction visually estimated from the bridge for stations Ice1, Ice2, Ice3, and Ice4.

tions from bulk salinities and sea ice temperatures following equations from Leppäranta and Manninen (1988) for sea ice temperatures $>-2{ }^{\circ} \mathrm{C}$ (Fig. 3). Due to logistical constraints mentioned above, neither ice nor snow measurements were conducted at station Ice2.

Melt pond depth, length, and width were determined using a graduated stick and a tape ruler. Melt pond water temperature was measured using a high-precision thermometer (61220-601 digital data logger, VWR) and water salinity was measured using the conductivity probe mentioned in the previous paragraph (Table 2). For each sampling location, two to three members of the research team visually assessed the pond fraction based on pictures taken from the bridge (see Fig. 1c for examples) and a mean value was calculated.

\subsection{Phytoplankton biomass and enumeration, bacterial count}

For Chl $a$ quantification, 1000 to $1500 \mathrm{~mL}$ duplicates of in situ pond water were filtered onto Whatman ${ }^{\circledR}$ GF/F $25 \mathrm{~mm}$ filters. Pigments were extracted in $90 \%$ acetone for 18 to $24 \mathrm{~h}$ in the dark at $4{ }^{\circ} \mathrm{C}$ (Parsons et al., 1984). Fluorescence of the extracted pigments was measured on board with a Turner Designs fluorometer (model 10-005R; Turner Designs, Inc.) before and after acidification with $5 \% \mathrm{HCl}$. The fluorometer was calibrated with a commercially available Chl $a$ standard (Anacystis nidulans, Sigma). Chl a concentrations were calculated using the equation provided by Holm-Hansen et al. (1965).

Microscopic identification and enumeration of eukaryotic cells $>2 \mu \mathrm{m}$ were conducted in each melt pond. Samples of $250 \mathrm{~mL}$ were collected and preserved with acidic Lugol solution ( $0.4 \%$ final concentration; Parsons et al., 1984), then stored in the dark at $4{ }^{\circ} \mathrm{C}$ until analysis was conducted by inverted microscopy (Lund et al., 1958; Parsons et al., 1984). For each sample, a minimum of 400 cells (accuracy $\pm 10 \%$ ) and three transects of $20 \mathrm{~mm}$ were counted at a magnification of $400 \times$. The main taxonomic references used to identify the eukaryotic cells are Tomas and Hasle (1997), BérardTherriault et al. (1999), and Throndsen et al. (2003).

The abundance of bacteria was determined by flow cytometry (Marie et al., 2005). Duplicate $4 \mathrm{~mL}$ subsamples were fixed with $20 \mu \mathrm{L}$ of $25 \%$ glutaraldehyde Grade I (0.1\% fi- 
Table 1. Physical characteristics of the sea ice surrounding the melt ponds. Note that only melt pond sampling (i.e. no ice sampling) was conducted at station Ice2 due to ship-related logistical constraints. A negative freeboard height indicates that the ice surface was locally below the mean sea level. NA stands for non-available data. Ice thickness and freeboard values are averages of 7 (Ice1) to 8 (Ice3 and Ice4) ice cores sampled at each station.

\begin{tabular}{llrrr}
\hline Station & $\begin{array}{l}\text { Sampling } \\
\text { date }\end{array}$ & $\begin{array}{r}\text { Snow and } \\
\text { frozen snow } \\
\text { depth }(\mathrm{m})\end{array}$ & $\begin{array}{r}\text { Ice } \\
\text { thickness } \\
(\mathrm{m})\end{array}$ & $\begin{array}{r}\text { Freeboard } \\
(\mathrm{m})\end{array}$ \\
\hline Ice1 & 18 Jul 2014 & 0 & $1.21 \pm 0.02$ & $-0.01 \pm 0.01$ \\
Ice2 & 20 Jul 2014 & 0 & $\mathrm{NA}$ & $\mathrm{NA}$ \\
Ice3 & 21 Jul 2014 & $0+0.07^{*}$ & $1.13 \pm 0.07$ & $0.10 \pm 0.02$ \\
Ice4 & 23 Jul 2014 & 0 & $1.27 \pm 0.01$ & $0.07 \pm 0.04$ \\
\hline
\end{tabular}

nal concentration; Sigma-Aldrich G5882), then subjected to quick-freeze in liquid nitrogen for $24 \mathrm{~h}$, and finally stored at $-80^{\circ} \mathrm{C}$ until analysis. Samples were analyzed using a FACS Calibur FCB3 flow cytometer (Becton Dickinson). Heterotrophic bacteria samples were stained with SYBR Green I and measured at $525 \mathrm{~nm}$ to quantify bacteria with low nucleic acid (LNA; potentially less active) and high nucleic acid (HNA; potentially more active) content (Gasol and del Giorgio, 2000; Lebaron et al., 2001). Analysis were performed on an Epics Altra flow cytometer (Beckman Coulter), fitted with a $488 \mathrm{~nm}$ laser ( $15 \mathrm{~mW}$ output; blue), using Expo32 v1.2b software (Beckman Coulter).

\subsection{DMS(P) sampling, conservation and analysis}

Duplicate samples for total DMSP (DMSP ${ }_{t}$ ), dissolved DMSP $\left(\mathrm{DMSP}_{\mathrm{d}}\right)$ and DMS measurements were collected from the melt ponds using a submersible pump (Cyclone Aquameric $^{\mathrm{TM}}$ ) connected to a sealed lead-acid battery and fitted with LDPE tubing. The pump was placed close to the pond bottom, without touching the ice. Stratification was reported in open melt ponds (i.e. melt ponds that have melted all the way to the sea surface) in Arctic FYI (Jung et al., 2015). However, closed FYI melt pond, such as those sampled during this study, are not prone to vertical stratification due to convective- and wind-driven mixing (Skyllingstad and Paulson, 2007). Given their shallow depths (less than $0.3 \mathrm{~m}$ ), melt pond stratification was most probably inexistent or minimal during our study. Glass serum bottles were filled with sampled water, temporarily sealed with a butyl cap and an aluminum lid, and kept in the dark in a cooler until analysis upon return to the ship. Analysis were performed using a purge and trap (PnT) system coupled to a Varian ${ }^{\mathrm{TM}} 3800$ gas chromatograph (GC), equipped with a pulsed flame photometric detector (PFPD). Analytical precision of the method was better than $5 \%$. Analytical d.l. was $0.01 \mathrm{nmol} \mathrm{L}^{-1}$ for all sulfur compounds. The protocol is a modified version of the method of Leck and Bågander (1988) as described in Scarratt et al. (2000) and further revised in Lizotte et
Table 2. Physical characteristics of the melt pond water. For melt pond depth, mean \pm standard deviation values are presented.

\begin{tabular}{llrrr}
\hline Station & Melt pond no. & $\begin{array}{r}\text { Melt pond } \\
\text { depth }(\mathrm{m})\end{array}$ & $\begin{array}{r}\text { Melt pond } \\
\text { salinity }\end{array}$ & $\begin{array}{r}\text { Melt pond } \\
\text { Temperature }\left({ }^{\circ} \mathrm{C}\right)\end{array}$ \\
\hline Ice1 & MP1 & $0.18 \pm 0.01$ & 5.2 & 1.9 \\
Ice1 & MP2 & $0.18 \pm 0.04$ & 4.1 & 1.8 \\
Ice2 & MP1 & $0.29 \pm 0.05$ & 0.7 & 0.4 \\
Ice2 & MP2 & $0.19 \pm 0.03$ & 0.4 & 0.3 \\
Ice2 & MP3 & $0.12 \pm 0.01$ & 0.2 & 0.2 \\
Ice3 & MP1 & $0.07 \pm 0.01$ & 1.1 & 0.2 \\
Ice3 & MP2 & $0.10 \pm 0.00$ & 0.9 & 0.2 \\
Ice4 & MP1 & $0.12 \pm 0.01$ & 8.1 & 0.2 \\
Ice4 & MP2 & $0.11 \pm 0.02$ & 8.5 & 0.3 \\
\hline
\end{tabular}

al. (2012). Briefly, DMS was stripped from liquid samples using helium gas (Praxair ${ }^{\mathrm{TM}} \mathrm{He}$, purity $99.999 \%$ ) flowing at $50 \pm 5 \mathrm{~mL} \mathrm{~min}^{-1}$ in the PnT system. One to $5 \mathrm{~mL}$ of sample was injected in the PnT. Five $\mathrm{mL}$ of Milli- ${ }^{\mathrm{TM}}$ water (Millipore filter system, Millipore Co., Bedford, MA, USA) was subsequently pushed into the system to completely flush the sample into the glass bubbling chamber. The outer walls of the bubbling chamber were heated at $70^{\circ} \mathrm{C}$ with a circulating bath. Humidity in the gas sample downstream of the bubbling step was minimized using a $4{ }^{\circ} \mathrm{C}$ circulating bath to trigger condensation. A Nafion ${ }^{\circledR}$ membrane separated the gas sample and He-carrier gas from a drying $\mathrm{He}$ counterflow set at $100 \mathrm{~mL} \mathrm{~min}^{-1}$ to further desiccate the gas sample. Fluxes in the PnT system were monitored using a flowmeter $\left(\operatorname{Varian}^{\mathrm{TM}}{ }^{\mathrm{M}}\right.$ ).

For DMSP ${ }_{t}$ samples, $3.5 \mathrm{~mL}$ of melt pond water was collected in duplicate into a $5 \mathrm{~mL}$ Falcon ${ }^{\mathrm{TM}}$ tube. $\mathrm{DMSP}_{\mathrm{d}}$ samples were obtained using the less disruptive small-volume gravity drip filtration (SVDF) method (Kiene and Slezak, 2006). Particulate DMSP $\left(\right.$ DMSP $\left._{\mathrm{p}}\right)$ concentrations were calculated by subtracting $\mathrm{DMSP}_{\mathrm{d}}$ from $\mathrm{DMSP}_{\mathrm{t}}$. DMSP samples were preserved with $50 \mu \mathrm{L}$ of $50 \%$ sulfuric acid $\left(\mathrm{H}_{2} \mathrm{SO}_{4}\right)$ to prevent DMSP transformation and remove pre-existing DMS. Samples were analyzed using the same methods as described above for DMS samples, following mole-to-mole conversion of DMSP into DMS via $\mathrm{NaOH}$ (5 M) hydrolysis (Dacey and Blough, 1987).

\subsection{Process studies}

In order to examine the pathways of in situ DMS production in melt ponds, three $24 \mathrm{~h}$ incubation experiments were conducted with water from the MP1 sampled at stations Ice1, Ice3, and Ice4. Water from the melt ponds was collected using the pump described in Sect. 2.3, pooled in clean 19L Coleman $^{\text {TM }}$ cooler jugs on site, and then transferred into gastight $3 \mathrm{~L}$ polyvinyl fluoride Tedlar ${ }^{\circledR}$ bags. Light transmittance through the incubation bag material diminished with decreasing light wavelength. Between 99 and $92 \%$ of the photosynthetically active radiations (PAR, $400-700 \mathrm{~nm}$ ) were transmitted through the bag material. Transmittances of ultravi- 
olet A radiations (UVA, $315-400 \mathrm{~nm}$ ) and ultraviolet B radiations (UVB, 290-315 nm) ranged between 92 and 82 and between 82 and $38 \%$, respectively. The incubation bags were rinsed once with $\sim 10 \% \mathrm{HCl}$, three times with Milli- $\mathrm{Q}^{\mathrm{TM}}$ water, and twice with melt pond water to avoid contamination. The bags were custom-built and pre-closed on three sides (Dalian Delin Gas Packaging Co., Ltd.). After the addition of the melt pond water, the bags were sealed with Clip-n$\mathrm{seal}^{\mathrm{TM}}$ Teflon closure devices. A valve was fitted to each bag to allow the removal of any remaining bubbles.

The samples were subjected to three duplicate treatments (total of six bags): (1) two bags of unaltered melt pond water incubated under natural light (control), (2) two bags amended with D6-DMSP and ${ }^{13} \mathrm{C}$-DMSO $\left(100 \mathrm{nmol} \mathrm{L}^{-1}\right.$, final concentration each) incubated under natural light (lightDMSP/O or L-DMSP/O), and (3) two bags amended with D6-DMSP and ${ }^{13} \mathrm{C}$-DMSO $\left(100 \mathrm{nmol} \mathrm{L}^{-1}\right.$, final concentration each) incubated in the dark (dark-DMSP/O or DDMSP/O). L- and D-DMSP/O bags were amended with $\sim 100 \mu \mathrm{L}$ of freshly thawed aliquots of two D6-DMSP and ${ }^{13} \mathrm{C}$-DMSO stock solutions (high purity $>99 \%$, SigmaAldrich ${ }^{\circledR}$ ). The high concentrations of isotopes added aimed to trigger a rapid and clear biological response (i.e. potential DMS production rates) measurable during our $24 \mathrm{~h}$ incubations. DMSP and DMSO uptake are not expected to be mutually exclusive and have been observed concomitantly both in live cultures (Spiese et al., 2009) and in situ (Asher et al., 2011).

Bags were incubated on the foredeck of the ship. The temperature was kept as near to in situ water temperature as possible by continuously flowing surface seawater in the incubator. The temperatures of the incubation water for Ice1-MP1, Ice3-MP1, and Ice4-MP1 were $1.29 \pm 1.75,-0.28 \pm 0.26$, and $-0.73 \pm 0.09^{\circ} \mathrm{C}$, respectively. These mean values were within $1{ }^{\circ} \mathrm{C}$ of the in situ melt pond water temperatures (Table 2).

$\mathrm{DMSP}_{\mathrm{t}}, \mathrm{DMSP}_{\mathrm{d}}$, and DMS concentrations were measured in duplicate every $6 \mathrm{~h}$ during the incubation period as described above. DMS production from DMSP cleavage and DMSO reduction were determined through gas chromatograph-mass spectrometry (GC-MS) analysis as an increase of D6-DMS and ${ }^{13} \mathrm{C}$-DMS, respectively, in the LDMSP/O and D-DMSP/O treatments. Discrimination by the microorganisms toward lighter (natural) isotopes of DMSP and DMSO is expected to be minimal $(<10 \%)$ according to Elizabeth Colleen Asher (unpublished data). The observed rates of change in the concentration of DMS stable isotopes are thus assumed to be representative of the potential for DMS cycling in these melt ponds.

This experimental setup allows the measurement of the following rates over 6 and $24 \mathrm{~h}$ : (1) net changes of in situ $\mathrm{DMSP}_{\mathrm{d}}$ and $\mathrm{DMSP}_{\mathrm{p}}$ in natural light derived from the difference of $\mathrm{DMSP}_{d}$ and $\mathrm{DMSP}_{\mathrm{p}}$ concentrations versus time in the controls, respectively; (2) net in situ microbial DMS production in natural light derived from the regression slope of
DMS versus time in the controls; (3) net potential $\mathrm{DMSP}_{\mathrm{d}}$ changes in natural light and in the dark derived from the regression slope of $\mathrm{DMSP}_{\mathrm{d}}$ versus time in L-DMSP/O and DDMSP/O; (4) net potential DMS production rate in natural light and in the dark derived from the regression slope of DMS versus time in L-DMSP/O and D-DMSP/O. The daily rates were obtained from the slopes between final and initial concentrations over $24 \mathrm{~h}$. Our experimental setup also allows the estimation of the relative contribution of DMSP and DMSO to the production of DMS, using the discrimination of the different isotopes of DMS (see Sect. 2.5).

\subsection{DMS isotopic signatures}

The discrimination of the different isotopic forms of DMS, including D6-DMS and ${ }^{13} \mathrm{C}-\mathrm{DMS}$ stemming from D6DMSP cleavage and ${ }^{13} \mathrm{C}$-DMSO reduction, respectively, was performed using GC-MS analysis following purging as described hereafter. Two sets of DMS sample duplicates were taken for the incubation experiments. The first set of duplicates was measured directly on board using the $\operatorname{Varian}^{\text {TM }}$ 3800 GC described in Sect. 2.2. The second set of DMS duplicates was preserved through cryo-trapping. Cryo-trapping of DMS was conducted using glass GC liners filled with Tenax-TA polymer (high sulfur affinity) (Pio et al., 1996; Zemmelink et al., 2002; Pandey and Kim, 2009) kept at $-80^{\circ} \mathrm{C}$ prior to their use and maintained below $-10^{\circ} \mathrm{C}$ during the 5 min purging and trapping process. The Tenax-filled deactivated liners were mounted downstream of the PnT system described earlier. After gas extraction from the liquid samples, Tenax liners and their DMS content were wrapped individually in aluminum foil, placed in a Pyrex ${ }^{\mathrm{TM}}$ glass tube sealed with a Teflon lid, and returned to the $-80^{\circ} \mathrm{C}$ freezer for several weeks until analysis on a land-based GC-MS.

Quantification of D6-DMS and ${ }^{13} \mathrm{C}-\mathrm{DMS}$ was conducted via GC-MS analysis (6978 GC coupled to a 7000B TripleQuad MS from Agilent). Mass spectra were collected both in full scan $(m / z 45-100)$ and in selected ion monitoring $(m / z 62,63$, and 68) modes. Final concentrations were calculated from standard curves using known concentrations of both unlabelled DMS and labelled DMS carrying the D6DMS and ${ }^{13} \mathrm{C}$-DMS signatures. The comparison between fresh DMS samples measured directly on board during the NETCARE/ArcticNet campaign and cryo-preserved DMS samples shows excellent agreement between the two methods $\left(r^{2}=0.96\right.$, Fig. 2$)$.

\subsection{Satellite data}

Distances between each stations and the open ocean were assessed using scaled NASA's Earth Observing System Data and Information System (EOSDIS) imagery. Maps of the ice cover were accessed for the sampling dates in July 2014 through the MODIS (Terra/Aqua) Corrected Reflectance (True Color) layer combined with MODIS (Terra) Cor- 


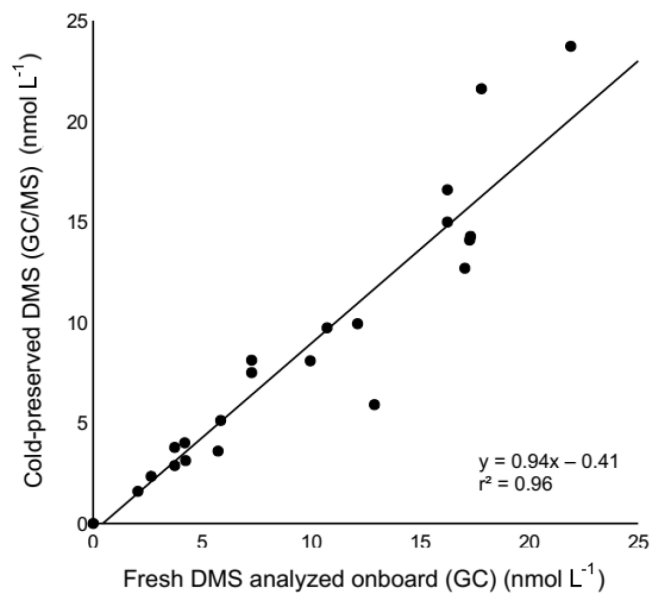

Figure 2. Relationship between the concentrations of fresh DMS samples measured on board the ship via gas chromatography during the campaign and the concentrations of the corresponding preserved duplicate samples measured via coupled gas chromatography and mass spectrometry in a laboratory setting. The concentrations of the preserved DMS samples plotted are the sum of the three isotopes of DMS investigated in this study $(\mathrm{m} / \mathrm{z}$ of 62,63 , and 68 ; see Materials and Methods).

rected Reflectance (bands 3, 6, 7). These open-source data are accessible through the Global Imagery Browse Services (GIBS) (https://worldview.earthdata.nasa.gov, last access: August 2017). The imagery had a resolution of $250 \mathrm{~m}$ on a daily scale.

\subsection{Statistical analysis}

Normality of the data was assessed using the Shapiro-Wilk test with a 0.05 significance level ( $\mathrm{R}$ statistical software, $\mathrm{R}$ Core Team, 2016), which revealed that most variables were non-normally distributed $(n=9, \mathrm{df}=8, \alpha=0.05)$. Nonparametric Spearman's rank correlation test $\left(r_{\mathrm{s}}\right)$ with a 0.05 significance level was used to assess correlation between key variables since normality could not be achieved uniformly through standard normalization methods. Model I linear regressions $\left(r^{2}\right)$ were used to determine biological rates during the incubation experiments (Sokal and Rohlf, 1995).

A non-parametric Mann-Whitney U test was used to determine whether the distributions of reduced-sulfur compounds (i.e. DMS, DMSP ${ }_{p}$, and $\mathrm{DMSP}_{\mathrm{d}}$ ) in the Ice1-MP1 and Ice4-MP1 incubations experiments were statistically different from one another. The difference in reduced-sulfur compound concentrations between the two incubation experiments was not found to be statistically significant $(n=45$, $\mathrm{df}=16, \alpha=0.05$ ).

Based on the results of the Mann-Whitney U test, a series of Wilcoxon signed-rank tests with a significance level $\alpha=0.05$ were conducted on the combined data sets of stations Ice1-MP1 and Ice4-MP1 in order to (1) assess the presence of statistical differences between the controls and each treatment L-DMSP/O and D-DMSP/O and (2) assess the potential effect of light on the concentrations and change rates of the reduced-sulfur compounds under study (DMS, $\mathrm{DMSP}_{\mathrm{d}}$, and DMSP $\mathrm{p}$ ) by comparing paired dependent samples (repeated measures) from L-DMSP/O and D-DMSP/O.

\section{Results}

\subsection{Ponded sea ice and snow properties}

The physical characteristics of the sea ice surrounding the melt ponds are presented in Table 1 and in Fig. 3. All the sampling sites were characterized by FYI, which was the predominant ice type throughout the region under study. Averaged sea ice thickness around the melt ponds were relatively uniform, varying between $1.13 \pm 0.07$ and $1.27 \pm 0.01 \mathrm{~m}$ at the different sites. Average freeboard values were relatively more variable. Station Ice 1 was characterized by low ice freeboards $-0.01 \pm 0.01 \mathrm{~m}$. Station Ice 3 had the highest positive freeboards with $0.10 \pm 0.02 \mathrm{~m}$. Station Ice4 freeboards were also positive and showed the greatest variability, with $0.07 \pm 0.04 \mathrm{~m}$.

Brine volume fraction was calculated using sea ice salinity and temperature values and used as a proxy of sea ice permeability (Fig. 3). Averaged values for bulk sea ice salinity over the full thickness of the ice were 1.73, 2.83, and 3.75 at stations Ice1, Ice3, and Ice4, respectively. Maximum bulk salinity never exceeded 5.00 (Ice4, 1.2-1.3 m section). In situ temperatures, averaged over the full thickness of the ice, were $-0.54,-0.52$, and $-0.98^{\circ} \mathrm{C}$ at stations Ice 1, Ice 3 , and Ice 4 , respectively, and reached a minimum value of $-1.39^{\circ} \mathrm{C}$ (Ice 4, $0.8-0.9 \mathrm{~m}$ section). Brine volume fraction constantly exceeded $10 \%$ in the ice profiles except in the upper $0.1 \mathrm{~m}$ section of the Ice 3 station, where we likely observed the effects of refreezing metamorphosis of snow and/or sea ice recrystallization. Snow meltwater percolation and refreezing can form such superimposed ice layers as observed at station Ice3. The resulting impermeable layer at the top of the ice contributed to the high freeboard $(0.1 \mathrm{~m})$ measured at this station, representing $6 \%$ of the total ice thickness. Visual estimates of the pond fraction ranged from 30 to $60 \%$ (see Fig. 1c) and the remaining surface of sea ice was bare ice at stations Ice1, Ice2, and Ice4.

\subsection{Physical, chemical, and biological characteristics of the melt pond water}

The physical and chemical characteristics of the melt ponds are presented in Table 2. All melt ponds were closed melt ponds, i.e. not directly connected with the water column (Lee et al., 2012). The mean depth of the individual melt ponds ranged from 0.07 to $0.29 \mathrm{~m}$, with length and width varying between 1.00 and $25.00 \mathrm{~m}$ (Fig. 1). Melt pond water temperatures and salinities varied between 0.21 and $1.86^{\circ} \mathrm{C}$ and between 0.2 and 8.5, respectively. $\mathrm{Chl} a$ concentrations were 
(a)

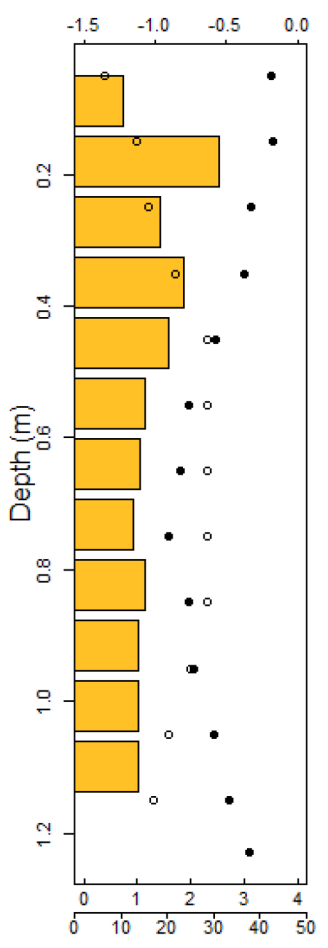

(b)

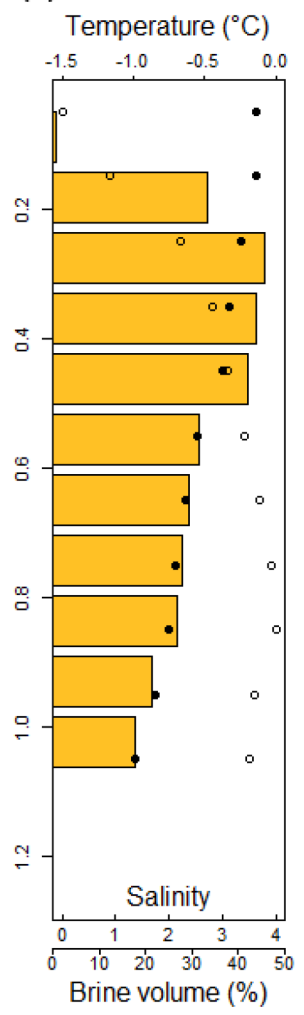

(c)

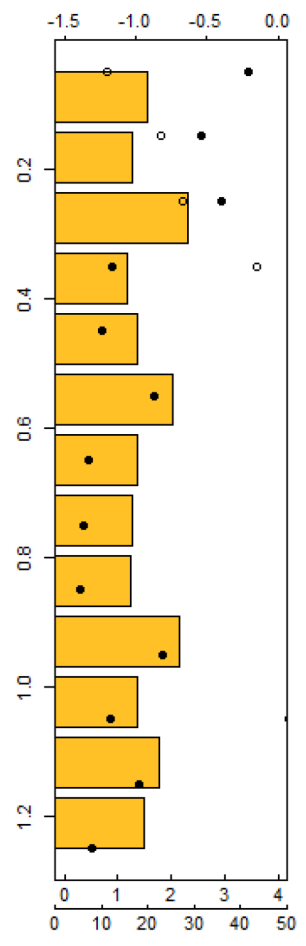

Figure 3. In situ temperature (•) and bulk ice salinity (o) profiles of the sea ice surrounding the melt ponds sampled at stations Ice1 (a), Ice3 (b), and Ice4 (c). Temperature and salinity values of each $0.1 \mathrm{~m}$ sea ice section were used to calculate brine volumes (orange bars), an indicator of sea ice permeability, throughout the full depth of sea ice (Cox and Weeks, 1983; Petrich and Eicken, 2010).

variable, ranging from 0.03 to $0.48 \mu \mathrm{g} \mathrm{L}-1$ with a mean of $0.20 \mu \mathrm{g} \mathrm{L}^{-1}$ (Table 3). The composition of the algal assemblage present in the melt ponds will be described in detail in a companion paper (Charette et al., 2018) but is summarized in Table 3. The algal assemblages were dominated by unidentified flagellates, ice-associated pennate diatoms, and chrysophytes. Empty diatom frustules were abundant in all melt ponds. Abundance of heterotrophic bacteria with HNA content varied between 0.02 and $0.24 \times 10^{9}$ cells L $^{-1}$ (Table 3 ).

In situ $\mathrm{DMSP}_{\mathrm{p}}$ and $\mathrm{DMSP}_{\mathrm{d}}$ concentrations ranged from 1.8 to $4.0 \mathrm{nmol} \mathrm{L}^{-1}$ and from below d.1. $\left(<0.01 \mathrm{nmol} \mathrm{L}^{-1}\right)$ to $1.4 \mathrm{nmol} \mathrm{L}^{-1}$, respectively. Melt pond DMS concentrations ranged from below d.l. to $6.1 \mathrm{nmol} \mathrm{L}^{-1}$ (Table 3). Spearman's rank correlation coefficients between key in situ variables measured in the melt ponds are presented in Table 4. DMS concentrations significantly co-varied with salinity $\left(r_{\mathrm{S}}=0.84, p<0.05\right)$ and Chl $a\left(r_{\mathrm{s}}=0.84, p<0.05\right)$. None of the other variables measured displayed significant relationships between each other (not shown).

\subsection{Dynamics and cycling of reduced-sulfur compounds in Arctic melt ponds}

Results from the Ice1-MP1 and Ice4-MP1 incubation experiments are presented in Fig. 4 (panels a and c, and panels $b$ and d, respectively). Results from the Ice3-MP1 experiments are not presented since DMSP ${ }_{d}$ and DMS concentrations showed no variation during the $24 \mathrm{~h}$ incubation period in the controls and in the amended treatments. This will be discussed in Sect. 4.2.2.

During the Ice1-MP1 incubation, initial $\mathrm{DMSP}_{\mathrm{d}}$ concentration was $1.30 \mathrm{nmol} \mathrm{L}^{-1}$ in the control and slightly increased to reach $5.3 \mathrm{nmol} \mathrm{L}^{-1}$ during the $24 \mathrm{~h}$ incubation period (Fig. 4a). In the light (L-DMSP/O) and dark (D-DMSP/O) amended treatments, $\mathrm{DMSP}_{\mathrm{d}}$ concentrations started at $102 \mathrm{nmol} \mathrm{L}^{-1}$, decreased to $\sim 35 \mathrm{nmol} \mathrm{L}^{-1}$ at $T_{6}$, and remained stable (dark treatments) or decreased to $10 \mathrm{nmol} \mathrm{L}^{-1}$ (light treatments) until $T_{24}$ (Fig. 4a). Concentrations of DMS in the control of Ice1-MP1 started at $3.0 \mathrm{nmol} \mathrm{L}^{-1}$, increased to $8.8 \mathrm{nmol} \mathrm{L}^{-1}$ between $T_{0}$ and $T_{6}$, and then decreased regularly to $4.2 \mathrm{nmol} \mathrm{L}^{-1}$ at $T_{24}$ (Fig. $4 \mathrm{c}$ ). The addition of labelled DMSP and DMSO stimulated DMS production. In the L-DMSP/O treatment, DMS concentrations increased to $12.6 \mathrm{nmol} \mathrm{L}^{-1}$ at $T_{6}$, remained at this level 
(a)

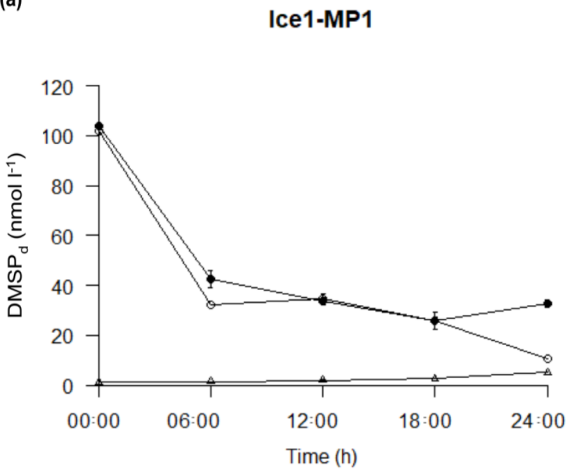

(c)

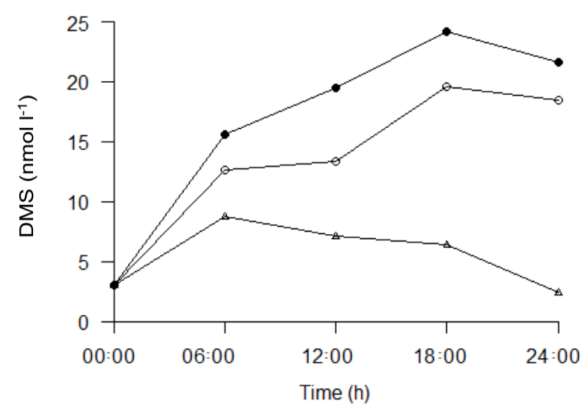

(b)

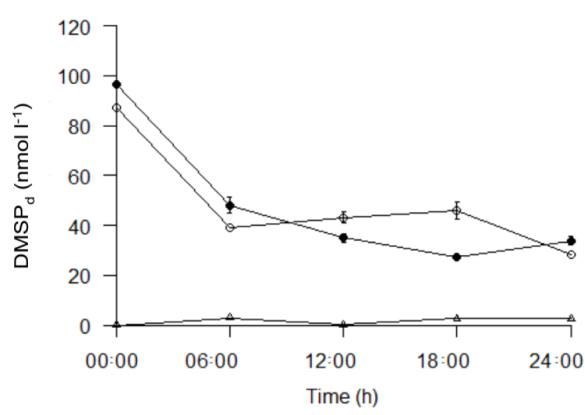

(d)

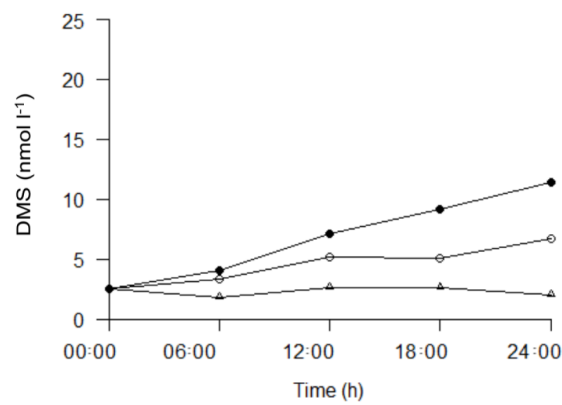

Figure 4. Temporal variations in $\mathrm{DMSP}_{\mathrm{d}}(\mathbf{a}, \mathbf{b})$ and DMS $(\mathbf{c}, \mathbf{d})$ concentrations during the Ice1-MP1 and Ice4-MP1 incubation experiments. Both light (o) and dark (•) treatments were initially amended with $100 \mathrm{nmol} \mathrm{L}^{-1}$ of both D6-DMSP and ${ }^{13} \mathrm{C}$-DMSO. Control treatments $(\triangle)$ mimic natural concentration changes over time. In panels $(\mathbf{a}, \mathbf{b})$, vertical bars represent standard errors of mean values between duplicate samples.

between $T_{6}$ and $T_{12}$, increased again between $T_{12}$ and $T_{18}$, and remained stable at $\sim 19 \mathrm{nmol} \mathrm{L}^{-1}$ between $T_{18}$ and $T_{24}$ (Fig. 4c). DMS concentrations were consistently higher in the D-DMSP/O treatment than in L-DMSP/O (Fig. 4c). They first reached $15.6 \mathrm{nmol} \mathrm{L}^{-1}$ at $T_{6}$, increased gradually to reach a peak value of $24.2 \mathrm{nmol} \mathrm{L}^{-1}$ at $T_{18}$, and decreased slightly to $21.6 \mathrm{nmol} \mathrm{L}^{-1}$ at $T_{24}$. Note that dissolved DMSO was not measured during this study due to methodological issues.

In the Ice4-MP1 incubation, DMSP $_{d}$ concentrations started at $3.0 \mathrm{nmol} \mathrm{L}^{-1}$ in the control and remained close to this value during the whole experiment (Fig. $4 \mathrm{~b}$ ). In the LDMSP/O and D-DMSP/O amended treatments, $\mathrm{DMSP}_{\mathrm{d}}$ concentrations started at 87 and $96 \mathrm{nmol} \mathrm{L}^{-1}$, respectively. As observed in the previous melt pond, the concentrations decreased to $\sim 45 \mathrm{nmol} \mathrm{L}^{-1}$ at $T_{6}$ and then slowly decreased to a value of $\sim 30 \mathrm{nmol} \mathrm{L}^{-1}$ at $T_{24}$ (Fig. $4 \mathrm{~b}$ ). DMS concentrations in the control of Ice1-MP1 started at $2.6 \mathrm{nmol} \mathrm{L}^{-1}$ and remained at this level during the $24 \mathrm{~h}$ experiment (Fig. 4d). In the L-DMSP/O treatment, DMS concentrations increased more or less linearly from $2.6 \mathrm{nmol} \mathrm{L}^{-1}$ at $T_{0}$ to $6.7 \mathrm{nmol} \mathrm{L}^{-1}$ at $T_{24}$. In the D-DMSP/O treatment, the increase in DMS concentrations was more pronounced than in the light treat- ment, and a maximal value of $11.5 \mathrm{nmol} \mathrm{L}^{-1}$ was reached at $T_{24}$.

In situ and potential change rates of the sulfur compounds during the incubation experiments are presented in Tables 5 and 6, respectively. Changes in $\mathrm{DMSP}_{\mathrm{d}}$, and to a lesser extent DMS concentrations, were generally not linear over the $24 \mathrm{~h}$ incubation period, with more pronounced variations during the first $6 \mathrm{~h}$. To take into account this non-linearity, both hourly rates measured between $T_{0}$ and $T_{6}$ and between $T_{6}$ and $T_{24}$, as well as daily rates $\left(T_{0}-T_{24}\right)$, are presented in these tables.

In Ice1-MP1, the concentrations of $\mathrm{DMSP}_{\mathrm{p}}$ in the control decreased at a rate of $2.2 \mathrm{nmol} \mathrm{L}^{-1} \mathrm{~d}^{-1}$ (Table 5). We measured no change in $\mathrm{DMSP}_{\mathrm{d}}$ during the first $6 \mathrm{~h}$, but a positive net increase of $4.0 \mathrm{nmol} \mathrm{L}^{-1}$ over the full $24 \mathrm{~h}$ incubation period was observed. In situ DMS changes increased by $1.0 \mathrm{nmol} \mathrm{L}^{-1} \mathrm{~h}^{-1}$ during the first $6 \mathrm{~h}$ and by $1.2 \mathrm{nmol} \mathrm{L}^{-1} \mathrm{~d}^{-1}$ over $24 \mathrm{~h}$. Potential net $\mathrm{DMSP}_{\mathrm{d}}$ change rates of -11.6 and $-10.2 \mathrm{nmol} \mathrm{L}^{-1} \mathrm{~h}^{-1}$ were measured during the first $6 \mathrm{~h}$ of incubation in L- and D-DMSP/O treatments, respectively (Table 6). These rates became -1.2 and $-0.6 \mathrm{nmol} \mathrm{L}^{-1} \mathrm{~h}^{-1}$ between $T_{6}$ and $T_{24}$ in L- and DDMSP/O, respectively. Over $24 \mathrm{~h}$, negative potential net 
Table 3. Reduced-sulfur compound concentrations measured in situ in the melt ponds and the associated biological characteristics (abundance of high nucleic acid (HNA) bacteria, Chl $a$ concentrations, and relative abundances of major taxonomic groups) of the melt pond water.

\begin{tabular}{|c|c|c|c|c|c|c|c|c|}
\hline Station & $\begin{array}{l}\text { Melt } \\
\text { pond }\end{array}$ & $\begin{array}{r}\text { In situ } \\
\mathrm{DMSP}_{\mathrm{p}} \\
\left(\mathrm{nmol} \mathrm{L}^{-1}\right)\end{array}$ & $\begin{array}{r}\text { In situ } \\
\mathrm{DMSP}_{\mathrm{d}} \\
\left(\mathrm{nmol} \mathrm{L}^{-1}\right)\end{array}$ & $\begin{array}{r}\text { In situ } \\
\text { DMS } \\
\left(\mathrm{nmol} \mathrm{L}^{-1}\right)\end{array}$ & $\begin{array}{r}\text { Abundance of } \\
\text { bacteria }(\mathrm{HNA}) \\
\left(\times 10^{9} \text { cells } \mathrm{L}^{-1}\right)\end{array}$ & $\begin{array}{r}\text { Total abundance } \\
\text { of algae } \\
\left(\times 10^{6} \text { cells L }^{-1}\right)\end{array}$ & $\begin{array}{r}\text { Chl } a \\
\left(\mu \mathrm{g} \mathrm{L}^{-1}\right)\end{array}$ & $\begin{array}{l}\text { Dominant algal } \\
\text { group }(\%)\end{array}$ \\
\hline \multirow[t]{2}{*}{ Ice1 } & MP1 & 2.2 & 1.3 & 3.0 & \multirow[t]{2}{*}{0.24} & \multirow[t]{2}{*}{2.00} & 0.48 & $\begin{array}{l}\text { Unidentified flagellates (50\%) } \\
\text { Prasinophytes (ca. } 25 \% \text { ) }\end{array}$ \\
\hline & MP2 & 2.0 & 1.4 & 3.1 & & & 0.40 & $\begin{array}{l}\text { Unidentified flagellates (55\%) } \\
\text { Prasinophytes (ca. } 25 \% \text { ) }\end{array}$ \\
\hline \multirow[t]{3}{*}{ Ice2 } & MP1 & 1.8 & d.l. & 0.0 & \multirow[t]{3}{*}{0.04} & \multirow[t]{3}{*}{0.50} & 0.03 & $\begin{array}{l}\text { Unidentified flagellates (90\%) } \\
\text { Pennate diatoms (ca. } 28 \% \text { ) }\end{array}$ \\
\hline & MP2 & 2.4 & d.l. & 0.0 & & & 0.09 & $\begin{array}{l}\text { Unidentified flagellates (50\%) } \\
\text { Pennate diatoms (ca. } 28 \% \text { ) }\end{array}$ \\
\hline & MP3 & 2.3 & d.l. & 0.0 & & & 0.06 & $\begin{array}{l}\text { Unidentified flagellates (70\%) } \\
\text { Pennate diatoms (ca. } 28 \% \text { ) }\end{array}$ \\
\hline \multirow[t]{2}{*}{ Ice3 } & MP1 & 2.0 & d.l. & 0.0 & \multirow[t]{2}{*}{0.02} & \multirow[t]{2}{*}{0.30} & 0.05 & $\begin{array}{l}\text { Unidentified flagellates ( } 45 \%) \\
\text { Chrysophytes (29\%) }\end{array}$ \\
\hline & MP2 & 2.3 & d.l. & 0.0 & & & 0.04 & $\begin{array}{l}\text { Unidentified flagellates (55\%) } \\
\text { Chrysophytes }(23 \%)\end{array}$ \\
\hline \multirow[t]{2}{*}{ Ice 4} & MP1 & 4.0 & d.1. & 2.6 & \multirow[t]{2}{*}{0.15} & \multirow[t]{2}{*}{1.00} & 0.18 & $\begin{array}{l}\text { Unidentified flagellates (50\%) } \\
\text { Pennate diatoms }(20 \%)\end{array}$ \\
\hline & MP2 & 3.7 & 1.1 & 6.1 & & & 0.20 & $\begin{array}{l}\text { Unidentified flagellates }(60 \%) \\
\text { Pennate diatoms }(25 \%)\end{array}$ \\
\hline
\end{tabular}

Table 4. Spearman's rank correlation coefficients between key in situ variables measured in the melt ponds.

\begin{tabular}{lrrrr}
\hline & DMS & Salinity & Temperature & Chl $a$ \\
\hline DMS & $0.84^{*}$ & 0.51 & $0.84^{*}$ \\
Salinity & & 0.40 & 0.56 \\
Temperature & & & 0.60 \\
\hline
\end{tabular}

* indicates a 0.05 significance level.

DMSP $_{\mathrm{d}}$ change rates of $\sim-91 \mathrm{nmol} \mathrm{L}^{-1}$ and $-71 \mathrm{nmol} \mathrm{L}^{-1}$ for the L-DMSP/O and D-DMSP/O treatments were calculated. Positive potential net DMS change rates of 1.6 and $2.1 \mathrm{nmol} \mathrm{L}^{-1} \mathrm{~h}^{-1}$ were measured during the first $6 \mathrm{~h}$ of incubation in L-DMSP/O and D-DMSP/O, respectively. For the complete $24 \mathrm{~h}$ incubation, potential net DMS change rates reached $15.4 \mathrm{nmol} \mathrm{L}^{-1} \mathrm{~d}^{-1}$ in the light and $18.6 \mathrm{nmol} \mathrm{L}^{-1} \mathrm{~d}^{-1}$ in the dark.

In Ice4-MP1, in situ DMSP $_{p}$ decreased at a rate of $1.9 \mathrm{nmol} \mathrm{L}^{-1} \mathrm{~d}^{-1}$ over the course of the incubation (Table 5). Meanwhile, in situ $\mathrm{DMSP}_{\mathrm{d}}$ changes rates were below the d.l. during the first $6 \mathrm{~h}$ and almost null over $24 \mathrm{~h}$ (Table 5). In situ DMS change rates were close to zero after $6 \mathrm{~h}$ and below d.l. after $24 \mathrm{~h}$. Potential net $\mathrm{DMSP}_{\mathrm{d}}$ change rates of $-8.1 \mathrm{nmol} \mathrm{L}^{-1} \mathrm{~h}^{-1}$ were measured during the first $6 \mathrm{~h}$ of incubation in both L- and D-DMSP/O (Table 6). These rates slowed down to -0.5 and $-0.9 \mathrm{nmol} \mathrm{L}^{-1} \mathrm{~h}^{-1}$ between $T_{6}$ and $T_{24}$, respectively. Over one day, average potential net DMSP $_{d}$ change rates of $\sim-59$ and $-62 \mathrm{nmol} \mathrm{L}^{-1}$ were calculated for the L-DMSP/O and D-DMSP/O treat- ments. Potential net DMS change rates remained low in both L-DMSP/O and D-DMSP/O treatments during the first $6 \mathrm{~h}$ of incubation with values at 0.1 and $0.3 \mathrm{nmol} \mathrm{L}^{-1} \mathrm{~h}^{-1}$, respectively. For the complete $24 \mathrm{~h}$ incubation, potential net DMS change rates in light and dark reached 4.2 and $8.9 \mathrm{nmol} \mathrm{L}^{-1} \mathrm{~d}^{-1}$, respectively.

During both Ice1-MP1 and Ice4-MP1 incubation experiments, the light versus dark treatment had no effect on the net changes in $\mathrm{DMSP}_{\mathrm{d}}$ concentrations between the LDMSP/O and D-DMSP/O treatments (Wilcoxon signedrank test; $n=8, \mathrm{df}=3, \alpha=0.05$ ), but significantly impacted the rates of net accumulation of DMS (Wilcoxon signedrank test; $n=12, \mathrm{df}=5, \alpha=0.05$ ). The accumulation of DMS over $24 \mathrm{~h}$ in the L-DMSP/O treatments were consistently and significantly lower than in the corresponding D-DMSP/O treatments (Wilcoxon signed-rank test; $n=8$, $\mathrm{df}=3, \alpha=0.05$ ). Based on the difference between the Land D-DMSP/O treatments after $24 \mathrm{~h}$, we estimated the lightassociated DMS sinks at $3.2 \mathrm{nmol} \mathrm{L}^{-1} \mathrm{~d}^{-1}$ in Ice1-MP1 and at $4.7 \mathrm{nmol} \mathrm{L}^{-1} \mathrm{~d}^{-1}$ in Ice4-MP1 (Table 6).

\subsection{Isotopic discrimination of DMS sources}

Table 7 shows the concentrations of DMS isotopes $(m / z 62)$ and $(m / z 68)$ after $24 \mathrm{~h}$ incubation in the three treatments and their relative contribution (\%) to the total DMS measured at $T_{24}$. As expected, $100 \%$ of the total DMS in the controls of the two experiments ( 3.0 and $2.3 \mathrm{nmol} \mathrm{L}^{-1}$ ) showed the isotopic signature of natural DMS $(m / z 62)$. In the L-DMSP/O treatment of the Ice1-MP1 incubation, $78 \%\left(14.4 \mathrm{nmol} \mathrm{L}^{-1}\right)$ of the DMS measured at $T_{24}$ derived from D6-DMSP addi- 
Table 5. In situ DMSP, DMSP $_{d}$, and DMS change rates measured during the incubation experiments conducted in melt ponds Ice1-MP1 and Ice4-MP1. Hourly rates for DMSP $\mathrm{d}_{\mathrm{d}}$ and DMS net changes measured between $T_{0}$ and $T_{6}$ are derived from the slope of DMSP $\mathrm{d}_{\mathrm{d}}$ and

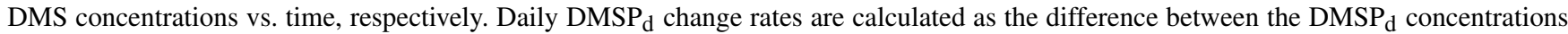
measured at $T_{24}$ and $T_{0}$. Daily DMS change rates are calculated as the difference between the DMS concentrations measured at $T_{24}$ and $T_{0}$. Rates measured over the first $6 \mathrm{~h}$ are expressed in $\mathrm{nmol} \mathrm{L}-1 \mathrm{~h}^{-1}$. Other rates are expressed in $\mathrm{nmol} \mathrm{L}-1 \mathrm{~d}^{-1}$.

\begin{tabular}{lr|rr|rr}
\hline Station & $\begin{array}{r}\text { In situ DMSP } \\
\text { change rates }\end{array}$ & \multicolumn{2}{|c|}{$\begin{array}{c}\text { In situ DMSP } \\
\text { change rates }\end{array}$} & \multicolumn{2}{c}{$\begin{array}{c}\text { In situ DMS } \\
\text { change rates }\end{array}$} \\
\cline { 2 - 7 } & $\left(\mathrm{nmol} \mathrm{L}^{-1} \mathrm{~d}^{-1}\right)$ & $\left(\mathrm{nmol} \mathrm{L}^{-1} \mathrm{~h}^{-1}\right)(6 \mathrm{~h})$ & $\left(\mathrm{nmol} \mathrm{L}^{-1} \mathrm{~d}^{-1}\right)$ & $\left(\mathrm{nmol} \mathrm{L}^{-1} \mathrm{~h}^{-1}\right)(6 \mathrm{~h})$ & $\left(\mathrm{nmol} \mathrm{L}^{-1} \mathrm{~d}^{-1}\right)$ \\
\hline Ice1 - MP1 & -2.2 & 0.0 & 4.0 & 1.0 & 1.2 \\
Ice 4 - MP1 & -1.9 & 0.0 & -0.1 & -0.1 & 0.0 \\
\hline
\end{tabular}

Table 6. Potential net DMSP $\mathrm{d}_{\mathrm{d}}$ change rates, potential net DMS change rates and light-associated DMS sinks measured during the incubation experiments conducted in melt ponds Ice1-MP1 and Ice4-MP1. Regular and bold font types regroup the rates measured under natural light (L-DMSP/O) and in the dark (D-DMSP/O), respectively. Hourly rates for potential DMSP $\mathrm{d}_{\mathrm{d}}$ and DMS net changes between $T_{0}$ and $T_{6}$ as well as $T_{6}$ and $T_{24}$ are derived from the slope of DMSP $\mathrm{d}_{\mathrm{d}}$ and DMS concentrations vs. time, respectively. Daily potential net DMSP $\mathrm{d}_{\mathrm{d}}$ change rates are calculated as the difference between the $\mathrm{DMSP}_{\mathrm{d}}$ concentrations measured at $T_{24}$ and $T_{0}$. Daily potential net DMS change rates are calculated as the difference between the DMS concentrations measured at $T_{24}$ and $T_{0}$. Rates of light-associated DMS sink were measured as the difference of DMS accumulation between L-DMSP/O and D-DMSP/O after the $24 \mathrm{~h}$ incubation. Rates measured over the first $6 \mathrm{~h}$ and

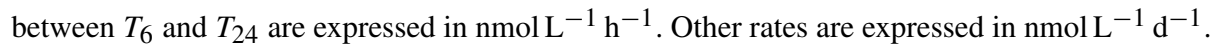

\begin{tabular}{|c|c|c|c|c|c|c|}
\hline \multirow[t]{2}{*}{ Station } & \multicolumn{3}{|c|}{ Potential net $\mathrm{DMSP}_{\mathrm{d}}$ change rates } & \multicolumn{2}{|c|}{ Potential net DMS change rates } & \multirow{2}{*}{$\begin{array}{r}\text { Light-associated DMS sinks } \\
\left(\mathrm{nmol} \mathrm{L}^{-1} \mathrm{~d}^{-1}\right)\end{array}$} \\
\hline & $\begin{array}{r}\left(\mathrm{nmol} \mathrm{L}^{-1} \mathrm{~h}^{-1}\right) \\
\left(T_{0}-T_{6}\right)\end{array}$ & $\begin{array}{r}\left(\mathrm{nmol} \mathrm{L}^{-1} \mathrm{~h}^{-1}\right) \\
\left(T_{6}-T_{24}\right)\end{array}$ & $\left(\mathrm{nmol} \mathrm{L}^{-1} \mathrm{~d}^{-1}\right)$ & $\begin{array}{r}(\mathrm{nmol} \mathrm{L} \\
\left.-1 \mathrm{~h}^{-1}\right) \\
\left(T_{0}-T_{6}\right)\end{array}$ & $\left(\mathrm{nmol} \mathrm{L} \mathrm{L}^{-1} \mathrm{~d}^{-1}\right)$ & \\
\hline \multirow[t]{2}{*}{ Ice $1-$ MP1 } & -11.6 & -1.2 & -91.5 & 1.6 & 15.4 & 3.2 \\
\hline & -10.2 & -0.6 & -71.3 & 2.1 & 18.6 & - \\
\hline \multirow[t]{2}{*}{ Ice4-MP1 } & -8.1 & -0.5 & -59.2 & 0.1 & 4.2 & 4.7 \\
\hline & -8.1 & -0.9 & -62.6 & 0.3 & 8.9 & - \\
\hline
\end{tabular}

tions $(m / z 68)$, with the remaining $22 \%\left(4.1 \mathrm{nmol} \mathrm{L}^{-1}\right)$ being natural DMS (Table 5). Similarly, $73 \%\left(18.2 \mathrm{nmol} \mathrm{L}^{-1}\right)$ of the DMS measured at $T_{24}$ derived from D6-DMSP additions in the D-DMSP/O treatment, with the remaining $27 \%$ $\left(6.6 \mathrm{nmol} \mathrm{L}^{-1}\right)$ carrying the signature of natural DMS.

In Ice4-MP1, $80 \%\left(5.1 \mathrm{nmol} \mathrm{L}^{-1}\right)$ of the DMS measured at $T_{24}$ in the L-DMSP/O treatment derived from the added D6-DMSP, with the remaining $20 \%\left(1.3 \mathrm{nmol} \mathrm{L}^{-1}\right)$ carrying the signature of natural DMS. For the D-DMSP/O treatment, $65 \%\left(7.9 \mathrm{nmol} \mathrm{L}^{-1}\right)$ of the DMS at $T_{24}$ derived from the D6DMSP addition with $35 \%\left(4.2 \mathrm{nmol} \mathrm{L}^{-1}\right)$ originating from natural DMS. The absence of $(m / z 63)$ DMS, regardless of the treatment, indicates that ${ }^{13} \mathrm{C}$-DMSO reduction was not contributing to the production of DMS during these two experiments $(\mathrm{m} / \mathrm{z} 63$ not shown in Table 7$)$. The match between the sum of DMS isotopes $(m / z 62$ and $m / z 68)$ and the total fresh DMS concentration measured on board (Fig. 2) also confirms the absence of DMSO-to-DMS reduction during our experiments.

\section{Discussion}

Research on DMS dynamics in melt ponds is in its infancy. Before this study, only four publications reported DMS measurements in melt ponds, two in the Arctic (Leck and Persson, 1996; Sharma et al., 1999) and the two others in the Antarctic (Asher et al., 2011; Nomura et al., 2012). In the Arctic, Leck and Persson (1996) reported negligible levels of DMS in MYI melt ponds while Sharma et al. (1999) measured concentrations reaching $2.2 \mathrm{nmol} \mathrm{L}^{-1}$. In the Antarctic, Nomura et al. (2012) reported DMS concentrations inferior to $3.7 \mathrm{nmol} \mathrm{L}^{-1}$ while Asher et al. (2011) measured levels up to $250 \mathrm{nmol} \mathrm{L}^{-1}$. Our results show that DMS concentrations in Arctic melt ponds may be at least 3 times higher (up to $\sim 6 \mathrm{nmol} \mathrm{L}{ }^{-1}$ ) than the first Arctic measurements and that both physical and biological processes can contribute to the accumulation of this climate-active gas in these transient environments. As discussed hereafter, evidences suggest that different ice cover dynamics and microbial communities are the two probable leading causes for the reported variability in DMS concentrations between melt ponds. 
Table 7. $(\mathrm{m} / \mathrm{z}$ 62) and $(\mathrm{m} / \mathrm{z}$ 68) DMS concentrations after $24 \mathrm{~h}$ incubation in the control, L-DMSP/O, and D-DMSP/O treatments. Relative contribution (\%) of natural DMS and D6-DMSP to the total DMS measured at $T_{24}$ in the control, L-DMSP/O, and D-DMSP/O treatments during the incubation experiments with water from Ice1-MP1 and Ice4-MP1. The natural DMS signature is $m / z 62$; the signature of DMS derived from D6-DMSP is $m / z 68$. No $(m / z 63)$, which represents the signature of DMS derived from ${ }^{13} \mathrm{C}$-DMSO, was retrieved either after $12 \mathrm{~h}$ (not shown) or $24 \mathrm{~h}$.

\begin{tabular}{llrrrr}
\hline Incubation & Treatment & $\begin{array}{r}(m / z 62) \mathrm{DMS} \\
\left(\mathrm{nmol} \mathrm{L}^{-1}\right)\end{array}$ & $\begin{array}{r}(m / z 68) \mathrm{DMS} \\
\left(\mathrm{nmol} \mathrm{L}^{-1}\right)\end{array}$ & $\begin{array}{r}(m / z 62) \% \text { of } \\
\text { total DMS }\end{array}$ & $\begin{array}{r}(\mathrm{m} / z \text { 68) } \% \text { of } \\
\text { total DMS }\end{array}$ \\
\hline \multirow{2}{*}{ Ice1 - MP1 } & Control & 3.0 & 0.0 & 100 & 0 \\
& L-DMSP/O & 4.1 & 14.4 & 22 & 78 \\
& D-DMSP/O & 6.6 & 18.2 & 27 & 73 \\
\hline \multirow{2}{*}{ Ice4 - MP1 } & Control & 2.3 & 0.0 & 100 & 0 \\
& L-DMSP/O & 1.3 & 5.1 & 20 & 80 \\
& D-DMSP/O & 4.2 & 7.9 & 35 & 65 \\
\hline
\end{tabular}

\subsection{Physical controls of DMS concentrations in melt ponds}

The strong relationship observed between DMS concentrations and salinity in the melt ponds sampled $\left(r_{\mathrm{s}}=0.84\right.$, $p \leq 0.05$, Table 4) suggests that salinization processes may play a crucial role in the initial seeding of DMS (and probably DMS-producing microbial assemblages) and the resulting cycling of DMS within melt ponds. Three main mechanisms could be involved in the salinization of closed melt ponds: (1) deposition of sea spray from the ice margin or leads, (2) brine intrusion, and (3) seawater intrusion through porous or low freeboard sea ice. For the reasons explained below, seawater intrusion through porous or low freeboard sea ice appears to be the most likely mechanism responsible for the salinization of the melt ponds during our study.

Sea spray probably did not contribute significantly to the salinization of the melt ponds during our study. The salinization of melt ponds could occur through sea spray deposition or seawater overflow during stormy events. Sea spray can transport salts over distances ranging from a few metres for the largest particles to a maximum distance of $\sim 30 \mathrm{~km}$ for finer aerosols, depending on wind speed (McArdle and Liss, 1995). This requires favourable wind direction, a relative proximity of the melt ponds with open water areas, and as demonstrated hereafter regarding the melt ponds studied here, unrealistic volumes of sea spray. During our study, the average volume of the melt ponds was $8 \mathrm{~m}^{3}$. We conservatively estimated that 19 to $367 \mathrm{~L}$ of sea spay (assuming an average sea surface salinity of 33) was required to increase melt pond salinity from zero to 0.2 or 8.5 , as measured during our study. Considering both the relatively large volume of sea spray required and the far-reaching distances $(>15 \mathrm{~km}$, estimated from MODIS data) of the sampled melt ponds from open water at the time of sampling, sea spray was unlikely the main source of salt in the melt ponds studied.

Ice brine intrusion is also unlikely to have contributed significantly to melt pond salinization since the averaged bulk ice salinity was low (under 5) and locally did not exceed 2 (top $0.2 \mathrm{~m}$ ). It is also known that most of the hyper-saline brine characterizing consolidated cold FYI in winter are lost in spring through full depth brine convection well before melt ponds start to form (Jardon et al., 2013). Residual salts are finally lost through meltwater flushing during the summer season (Weeks and Ackley, 1986; Eicken et al., 2002; Vancoppenolle et al., 2007). At the time of our sampling, low bulk salinity values, combined with calculated brine volume fraction constantly exceeding $10 \%$ in the entire sea ice profiles (except in the upper $0.1 \mathrm{~m}$ section of the Ice 3 station), suggest that full depth flushing had already occurred. We thus exclude sea ice brine enrichment of melt ponds as their main salinization mechanism.

Rather, we suggest that melt ponds salinization originated mostly from the intrusion of seawater through the ice. Although closed melt ponds are not visibly connected to seawater, exchanges with the underlying seawater can take place. The extent of these exchanges is dependent on the sea ice freeboard and micro-structure, i.e. the amount, size, and shape of brine inclusions (Carnat et al., 2013), that control sea ice permeability. Above a critical brine volume ranging between $5 \%$ (for columnar sea ice) and $10 \%$ (for granular sea ice), brine inclusions become interconnected. During the melting season, the decrease in sea ice thickness is enhanced by the formation of the melt pond and leads to a loss of freeboard. As melt ponds become closely levelled with seawater, small changes in ice temperature oscillating around the freezing temperature may result in episodic intrusion of seawater mixed with meltwater through the porous ice. Seawater mixed with meltwater entering the brine channels of permeable sea ice may bring salts, nutrients, and microorganisms (Jardon et al., 2013; Vancoppenolle et al., 2010), potentially reaching surface melt ponds. This mechanism most probably explains the salinity and biochemical characteristics of Ice1 and Ice 4 melt ponds. Station Ice 3 represents a different case. Here, the low melt pond salinity (and absence of biological activity) may be explained by the presence of an 
impermeable ice layer on the top of the ice preventing both pond drainage and exchange between pond water and seawater.

We acknowledge that our data set is too limited to draw firm conclusions on the processes leading to the formation and salinization of FYI melt ponds. However, in the interest of further research, we conjecture that snow load before melt onset may be crucial in determining the fate of melt ponds not only concerning their saline status, but also relatively to their potential to produce DMS. Brine volume, derived from bulk salinity and temperature, generally provides a valid proxy for sea ice permeability. In some cases, however, melting of high snowpack generates a considerable flow (up to $15 \mathrm{~cm} \mathrm{~d}^{-1}$ ) of freshwater into the porous structure of sea ice (Polashenski et al., 2017). This can create localized ice plugs within the highly connected brine network of apparently porous sea ice and allow melt ponds to persist above sea level well after brine volume reached a critical level $(5-10 \%)$. Such deviation from the porosity-permeability relationship following freshwater intrusion has been demonstrated in Polashenski et al. (2017). We suggest that we observed such a case of melt pond persistence above sea level at station Ice3. Alternatively, lower snow load remaining at the onset of the melt season will translate into a less abundant freshwater input above sea ice. Snow load distribution is notoriously highly variable even on the metre scale due to wind redistribution and sea ice topography variability (e.g. Polashenski et al., 2017). Locally low snowpack would induce limited insulation of the sea ice from atmospheric conditions, resulting in (1) a more gradual warming of sea ice during spring season and (2) limited meltwater available for percolation blockage. In this case, freshwater would not seal the ice through percolation blockage (Polashenski et al., 2017). Sea ice would then remain entirely porous as soon as the 5$10 \%$ brine volume threshold is reached, facilitating the melt pond salinization process. We suggest that this scenario may have been observed at stations Ice1 and Ice4.

\subsection{Biological control of DMS production in melt ponds}

\subsubsection{Simulated in situ conditions}

In addition to the physical mechanisms mentioned above, results from our incubation experiments show that biological production of DMS may take place in Arctic melt ponds under simulated in situ conditions and, to a greater extent, following DMSP enrichment. A daily net DMS production of $1.2 \mathrm{nmol} \mathrm{L}^{-1} \mathrm{~d}^{-1}$ was measured without substrate addition in one of the three melt ponds tested, Ice1-MP1 (Table 5). The absence of net daily increase in DMS in the two other melt ponds tested does not necessarily preclude potential gross production since, as discussed below, this production could be balanced by microbial DMS uptake and photolysis. Such a balance between DMS sources and sinks over a $24 \mathrm{~h}$ period has been previously observed during incubation ex- periments conducted with Labrador Sea water (Wolfe et al., 1999). However, this explanation probably does not explain the absence of accumulation of DMS in the freshwater melt pond Ice3-MP1 since the addition of substrate failed to stimulate DMS production (see Sect. 4.2.3).

\subsubsection{Source of DMS under substrate amended conditions}

Bacterial DMSP $_{d}$ metabolism was the main mechanism leading to DMS production in the melt ponds tested. None of the DMS measured carried the $(m / z 63)$ isotopic signature that would have indicated its ${ }^{13} \mathrm{C}$-DMSO origin. Extremely high gross DMS production rates from DMSO reduction, up to $105 \pm 24 \mathrm{nmol} \mathrm{L}^{-1} \mathrm{~d}^{-1}$, were measured within Antarctic sea ice brines by Asher et al. (2011). The authors suggested that this mechanism could also potentially be responsible for the high DMS concentrations (up to $250 \mathrm{nmol} \mathrm{L}^{-1}$ ) measured in Antarctic melt ponds. The absence of DMS production from ${ }^{13} \mathrm{C}$-DMSO in the melt ponds studied here may then reflect potential differences in microbial assemblages within melt ponds, as the metabolic ability to convert DMSO into DMS is not ubiquitous among bacterial communities (Hatton et al., 2012). In support of this hypothesis, it has been shown that between 70 and $78 \%$ of the operational taxonomic units (OTU), a marker of microbial diversity, in Arctic and Southern Ocean surface water communities are unique to their region (Ghiglione et al., 2012). Observed differences in the biological characteristics of melt ponds between the poles could also reflect divergent sea ice dynamics. Antarctic sea ice salinity is higher by 0.5 to $1.0 \%$ than in Arctic sea ice (Gow et al., 1982, 1987) and the C-shaped salinity profile that is typical in fully formed Arctic FYI is not as prominent in Southern Ocean sea ice (Eicken, 1992). Antarctic sea ice is commonly subjected to intense rafting, flooding, and the formation of snow ice (Hunke et al., 2011). Antarctic melt ponds studied in Asher et al. (2011) may have been subjected to flooding leading to the formation of salted "freeboard layers" (Haas et al., 2001; Massom et al., 2006). This hypothesis is highly plausible considering that highest salinities were reported in the top sea ice layers and salinity decreased throughout the ice profile. Such configuration may bring productive microbial communities at the surface of the ice, potentially responsible for the high DMS concentrations observed in melt ponds. The still limited availability of data, including other published studies, prevents us from making further conclusion about the specific reasons of the absence of DMS production from ${ }^{13} \mathrm{C}$-DMSO and compels additional exploration.

\subsubsection{Substrate limitation of microbial DMSP uptake and DMS production}

The addition of DMSP had a strong stimulating effect on the bacterial uptake of DMSP and the resulting production of 
DMS in the two brackish melt ponds tested. In both Ice1MP1 and Ice4-MP1, the response of the microbial assemblage to the addition of DMSP was rapid and intense (Fig. 4) as approximately half of the $\mathrm{DMSP}_{\mathrm{d}}$ added was consumed over the first $6 \mathrm{~h}$ and potential net DMS production increased substantially.

In the amended treatments, changes in the $\mathrm{DMSP}_{\mathrm{d}}$ concentrations over time proceeded into two distinct phases during the incubation period (Fig. 4a-c). Irrespective of the light regime, the first phase ( $T_{0}$ to $T_{6}$ ) was characterized by a rapid net decrease of DMSP $_{d}$ concentrations. Potential net DMSP change rates of $\sim-11$ and $-8.1 \mathrm{nmol} \mathrm{L}^{-1} \mathrm{~h}^{-1}$ in Ice1-MP1 and Ice4-MP1, respectively, were calculated (Table 6). These estimates represent minimum rates since our calculation assumes a linear uptake during the first $6 \mathrm{~h}$. Even so, these rates already translate an extremely steep decrease of $\mathrm{DMSP}_{\mathrm{d}}$ in comparison with those of -0.01 to $-0.2 \mathrm{nmol} \mathrm{L}^{-1} \mathrm{~h}^{-1}$ previously measured in the same region in the water column and under the ice cover in spring (Luce et al., 2011; Galindo et al., 2015). This difference most probably reflects the large amount of DMSP added in our experiments. The second phase of the incubation (from $T_{6}$ to $T_{24}$ ) shows an abrupt slowing down of the potential net $\mathrm{DMSP}_{\mathrm{d}}$ change rates, still slightly superior but closer to the range of in situ rates reported by the previous studies (Table 6). These results clearly show that an active microbial assemblage predisposed to $\mathrm{DMSP}_{\mathrm{d}}$ consumption inhabited the brackish melt ponds under study. This is in accordance with reported substrate limitation of bacterial growth in Arctic FYI melt ponds (Sørensen et al., 2017).

The bi-phasic DMSP uptake dynamics observed in our experiment suggests that DMSP additions at least temporarily fulfilled the microbial requirement for this substrate. Phytoplankton biomass, and probably dissolved organic carbon, was low in the melt ponds. In a context of substrate limitation, rapid uptake of $\mathrm{DMSP}_{\mathrm{d}}$ was expected. Fast and transient intracellular accumulation of compatible solutes, such as DMSP, may serve as an adaptive strategy by microbial cells to help cope with fluctuations of the surrounding environment, increasing their tolerance to osmotic and thermal stresses for example (Welsh, 2000). Such accumulations which could occur under replete conditions allow a so-called "luxury uptake" of compounds by microorganisms above their immediate requirements. Finally, the low HNA bacterial abundances measured in the melt ponds (Table 3) might explain the curtailing of $\mathrm{DMSP}_{\mathrm{d}}$ uptake measured after the initial rapid consumption.

Following DMSP $\mathrm{d}_{\mathrm{d}}$ addition, the potential daily net DMS production rates varied between 4.2 and $18.6 \mathrm{nmol} \mathrm{L}^{-1}$ in the two brackish melt ponds tested (Table 6). As previously mentioned, it was only within the freshwater Ice3-MP1 melt pond that potential to process DMSP and produce DMS was not detected, even when substrate limitation was alleviated by $\mathrm{DMSP}_{\mathrm{d}}$ addition. These different in situ and potential DMSP metabolisms and DMS production rates suggest that de novo DMS production in melt ponds is triggered only once a threshold in microbial biomass is reached. In support of this hypothesis, Chl $a$ concentration $\left(0.05 \mu \mathrm{g} \mathrm{L}^{-1}\right)$ and bacterial abundance $\left(0.02 \times 10^{9}\right.$ cells $\left.\mathrm{L}^{-1}\right)$ were extremely low in the unproductive freshwater Ice3-MP1: 1 order of magnitude lower than in the two productive brackish Ice1MP1 and Ice4-MP1 (Table 3).

In contrast with the simulated in situ conditions in the controls, net potential DMS production in the amended treatments constantly exceeded DMS loss through photolysis and bacterial consumption, resulting in a net accumulation of DMS throughout the $24 \mathrm{~h}$ of incubation (Fig. 4c, d). In spite of the atypically high DMSP level added, our $\mathrm{DMSP}_{\mathrm{d}}$ amendments could be considered as analogues of the $\mathrm{DMSP}_{\mathrm{d}}$ pulses that take place in the natural environment during the senescence phase of algal blooms or under high viral attack and grazing pressure. These pulses are known to contribute to transient DMS build-up at lower latitudes (e.g. Malin et al., 1993; Locarnini et al., 1998; Scarratt et al., 2000). At high latitudes, the inhibitory effect of low temperature on microbial DMS consumption may even exacerbate these build-ups. For instance, temperatures below $2{ }^{\circ} \mathrm{C}$ were found to potentially inhibit DMS consumption rates in the Labrador Sea (Wolfe et al., 1999). The sensitivity of DMS microbial uptake to low temperatures was proposed by Wolfe et al. (1999) as a potential driving mechanism responsible for the large pulses of DMS often measured in the Arctic environment. Cold and biologically active melt ponds may be prone to such DMS accumulation when the limitation in substrate is alleviated. However, our observations suggest that such events, which would require high biomass, may be rare in Arctic melt ponds.

\subsubsection{Influence of light on DMSP bacterial metabolism}

Light affected the accumulation of DMS in the DMSP/O amended treatments. The continuous light conditions prevailing during our incubation experiments reduced DMS accumulation in the L-DMSP/O treatments compared to the DDMSP/O treatments by $\sim 15 \%$ and up to $40 \%$ in Ice1-MP1 and Ice4-MP1, respectively (Fig. 4c, d). This negative effect of light was expected since photolysis is known as an important sink for DMS in the open ocean, sometimes as important as bacterial consumption in the near surface waters (Royer et al., 2016). However, removing light did not increase $\mathrm{DMSP}_{\mathrm{d}}$ removal rates (Fig. 4a, b). It should be pointed out that our incubation setup did not aim to reproduce the exact light field of the melt ponds where light backscattering could considerably increase DMS loss by photolysis. The importance of light as a sink for DMS in melt ponds should be thoroughly investigated in future studies. Light-induced DMS losses may be particularly relevant in melt ponds since DMS ventilation, another important sink for DMS (absent from our incubation setup), is probably limited at least in small melt ponds where fetch is minimal. 


\section{Conclusion}

Results from this study confirm the presence of DMS in Arctic melt ponds, with concentrations up to three times higher than those reported by the two other previous Arctic studies. Salinization of melt ponds appears to be a prerequisite to the presence of DMS and its de novo biological production. Intrusion of seawater through porous sea ice and low freeboard flooding seems to be a fundamental mechanism for bringing salt and DMS in the melt ponds as well as allowing the establishment of potential DMS-producing communities. As melt ponds become closely levelled with seawater, small changes in ice temperature oscillating around the freezing temperature may result in episodic intrusion of seawater mixed with meltwater through the porous ice. Seawater mixed with meltwater penetrating the brines channels of permeable sea ice may bring salts, nutrients, and microorganisms potentially seeding surface melt ponds. Results from incubation experiments reveal a modest but measurable in situ net production of DMS in one of the melt ponds tested. Our results also suggests that melt ponds can host an active bacterial assemblage associated with rapid DMSP uptake and significant production of DMS. Freshwater ponds lacked the potential to produce DMS, further confirming the importance of the seawater intrusion mechanism in the biological cycling of DMS in melt ponds. No DMSO-to-DMS reduction was detected in our study.

To this day, most climatologies assume the absence of DMS fluxes above ice-covered waters (e.g. Lana et al., 2011) even though several studies provide direct (Zemmelink et al., 2008; Nomura et al., 2012, MYI) and indirect (Carnat et al., 2014, FYI) evidence of DMS venting from snow-covered Antarctic sea ice. Arctic studies have also reported DMS exchanges above the ice-covered ocean, specifically highlighting the importance of particular zones such as open leads (Levasseur et al., 1994) and cracks in sea ice, as well as melt ponds (Sharma et al., 1999; Mungall et al., 2016). Here, we measured an average DMS concentration of $2.1 \mathrm{nmol} \mathrm{L}^{-1}$ $\left(<0.01-6.1 \mathrm{nmol} \mathrm{L}^{-1}\right)$ in nine FYI melt ponds. Although estimation of the actual DMS flux from the melt ponds sampled here is beyond the scope of our study, we argue that FYI melt ponds represent a non-negligible reservoir of DMS in the Arctic readily available for air-sea exchange. The estimation of the importance of melt ponds as net sources of DMS for the atmosphere will require an accurate evaluation of their spatial and temporal coverage, a better understanding of gas exchange between small fetch melt ponds and the atmosphere and its sensitivity to changing wind velocity, as well as comprehensive measurements of DMS within melt ponds at large, both FYI and MYI, and particularly at higher latitudes. How the strength of DMS emissions from melt ponds will respond to changes in Arctic climate is still unknown. Both the spatial extent of melt ponds and their temporal span have increased over the last three decades in connection with regional climate alterations (Stroeve et al., 2014; Agarwal et al., 2011). Meanwhile, MYI is increasingly being replaced by thinner FYI (e.g. Kwok et al., 2009), potentially promoting melt pond salinization processes through permeable sea ice. The importance of this ice-related source of DMS for the Arctic atmosphere could increase as a response of the structural changes of the Arctic ecosystem.

Data availability. Metadata are available on the Polar Data Catalog website at http://www.polardata.ca (Gourdal et al., 2017). Data are available on request by contacting the first author.

Author contributions. MG was responsible for the elaboration of the experimental design, the sampling process, the data analysis and processing, and the redaction of this paper. Several co-authors provided specific data included in the paper and all co-authors contributed to the final edition of the paper.

Competing interests. The authors declare that they have no conflict of interest.

Special issue statement. This article is part of the special issue "NETCARE (Network on Aerosols and Climate: Addressing Key Uncertainties in Remote Canadian Environments) (ACP/AMT/BG inter-journal SI)". It is not associated with a conference.

Acknowledgements. The authors wish to thank the commandant, officers, and crew of the Canadian icebreaker NGCC Amundsen for their support during the project. The authors are especially indebted to Jean-Sébastien Côté, Tim Papakyriakou, and Roghayeh Ghahremaninezhad for participating in the sample collection; Marjolaine Blais for pigment and bacterial abundance analysis; and Virginie Galindo for her extensive logistical support during the cruise. We thank Sylvie Lessard for cell identification. The authors would like to thank the reviewers for their valuable comments and suggestions to improve the quality of the paper. This project was funded by the Network on Climate and Aerosols: Addressing Key Uncertainties in Remote Canadian Environments (NETCARE), ArcticNet (Network of Centres of Excellence of Canada), the Canada Excellence Research Chair in Remote Sensing of Canada's New Arctic Frontier, and the Takuvik Joint International Laboratory. Partial funding was also provided by the Natural Sciences and Engineering Research Council of Canada (NSERC) and the Fonds de Recherche du Québec Nature et Technologies (FRQNT) through Québec-Océan. Funding support was also received from the Canadian Museum of Nature for cell counts analysis. The author received graduate scholarships from Université Laval and Takuvik UMI and stipends from NETCARE and Québec-Océan.

Edited by: Laurent Bopp

Reviewed by: Gauthier Carnat and one anonymous referee 


\section{References}

Agarwal, S., Moon, W., and Wettlaufer, J. S.: Decadal to seasonal variability of Arctic sea ice albedo, Geophys. Res. Lett., 38, L20504, https://doi.org/10.1029/2011GL049109, 2011.

Albrecht, B. A.: Aerosols, cloud microphysics, and fractional cloudiness, Science, 245, 1227-1231, 1989.

Aliabadi, A. A., Staebler, R. M., de Grandpré, J., Zadra, A., and Vaillancourt, P. A.: Comparison of Estimated Atmospheric Boundary Layer Mixing Height in the Arctic and Southern Great Plains under Statically Stable Conditions: Experimental and Numerical Aspects, Atmos.-Ocean, 54, 60-74, https://doi.org/10.1080/07055900.2015.1119100, 2016.

Asher, E. C., Dacey, J. W., Mills, M. M., Arrigo, K. R., and Tortell, P. D.: High concentrations and turnover rates of DMS, DMSP and DMSO in Antarctic sea ice, Geophys. Res. Lett., 38, L23609, https://doi.org/10.1029/2011GL049712, 2011.

Ayers, G. P. and Cainey, J. M.: The CLAW hypothesis: a review of the major developments, Environ. Chem., 4, 366-374, 2008.

Bates, T. S., Lamb, B. K., Guenther, A., Dignon, J., and Stoiber, R. E.: Sulfur emissions to the atmosphere from natural sources, J. Atmos. Chem., 14, 315-337, 1992.

Bates, T. S., Kiene, R. P., Wolfe, G. V., Matrai, P. A., Chavez, F. P., Buck, K. R., Blomquist, B., W., and Cuhel, R. L.: The cycling of sulfur in surface seawater of the northeast Pacific, J. Geophys. Res.-Oceans, 99, 7835-7843, 1994.

Bérard-Therriault, L., Poulin, M., and Bossé, L.: Guide d'identification du phytoplancton marin de l'estuaire et du golfe du Saint-Laurent, incluant également certains protozoaires, Publ. Spéc. Can. Sci. Halieut. Aquat, 128, 1-387, 1999.

Bopp, L., Boucher, O., Aumont, O., Belviso, S., Dufresne, J. L., Pham, M., and Monfray, P.: Will marine dimethylsulfide emissions amplify or alleviate global warming? A model study, Can. J. Fish. Aquat. Sci., 61, 826-835, 2004.

Browse, J., Carslaw, K. S., Arnold, S. R., Pringle, K., and Boucher, O.: The scavenging processes controlling the seasonal cycle in Arctic sulphate and black carbon aerosol, Atmos. Chem. Phys., 12, 6775-6798, https://doi.org/10.5194/acp12-6775-2012, 2012.

Burkart, J., Willis, M. D., Bozem, H., Thomas, J. L., Law, K., Hoor, P., Aliabadi, A. A., Köllner, F., Schneider, J., Herber, A., Abbatt, J. P. D., and Leaitch, W. R.: Summertime observations of elevated levels of ultrafine particles in the high Arctic marine boundary layer, Atmos. Chem. Phys., 17, 5515-5535, https://doi.org/10.5194/acp-17-5515-2017, 2017.

Bursa, A.: Phytoplankton in coastal waters of the Arctic Ocean at Point Barrow, Alaska, Arctic, 16, 239-262, 1963.

Carnat, G., Papakyriakou, T., Geilfus, N., Brabant, F., Delille, B., Vancoppenolle, M., Gilson, G., Zhou, J., and Tison, J.: Investigations on physical and textural properties of Arctic first-year sea ice in the Amundsen Gulf, Canada, November 2007-June 2008 (IPY-CFL system study), J. Glaciol., 59, 819-837, 2013.

Carnat, G., Zhou, J., Papakyriakou, T., Delille, B., Goossens, T., Haskell, T., Schoemann, V., Fripiat, F., Rintala, J.-M., and Tison, J.-L.: Physical and biogeochemical controls on DMSP dynamics in ice shelf influenced fast ice during a winter-spring and a spring-summer transitions, J. Geophys. Res.-Oceans, 119, 288229052014.

Carslaw, K. S., Lee, L. A., Reddington, C. L., Pringle, K. J., Rap, A., Forster, P. M., Mann, G. W., Spracklen, D.V, Woodhouse, M. T.,
Regayre, L. A., and Pierce, J. R.: Large contribution of natural aerosols to uncertainty in indirect forcing. Nature, 503, 67-71, 2013.

Chang, R. Y. W., Sjostedt, S. J., Pierce, J. R., Papakyriakou, T. N., Scarratt, M. G., Michaud, S., Levasseur, M., Leaitch, W. R., and Abbatt, J. P. D.: Relating atmospheric and oceanic DMS levels to particle nucleation events in the Canadian Arctic, J. Geophys. Res.-Atmos. 116, D00S03, https://doi.org/10.1029/2011JD015926, 2011.

Charette, J., Gosselin, M., Levasseur, M., Poulin, M., Blais, M., Tremblay, J.-É., and Bélanger, S.: Characterization of melt pond algal community and their photoprotection strategies in the Canadian Arctic, in preparation, 2018.

Charlson, R. J., Lovelock, J. E., Andreae, M. O., and Warren, S. G.: Oceanic phytoplankton, atmospheric sulphur, cloud albedo and climate, Nature, 326, 655-661, 1987.

Collins, D. B., Burkart, J., Chang, R. Y.-W., Lizotte, M., BoivinRioux, A., Blais, M., Mungall, E. L., Boyer, M., Irish, V. E., Massé, G., Kunkel, D., Tremblay, J.-É., Papakyriakou, T., Bertram, A. K., Bozem, H., Gosselin, M., Levasseur, M., and Abbatt, J. P. D.: Frequent ultrafine particle formation and growth in Canadian Arctic marine and coastal environments, Atmos. Chem. Phys., 17, 13119-13138, https://doi.org/10.5194/acp-1713119-2017, 2017.

Cox, G. F. and Weeks, W. F.: Equations for determining the gas and brine volumes in sea ice samples, J. Glaciol., 29, 306-316, 1983.

Croft, B., Martin, R. V., Leaitch, W. R., Tunved, P., Breider, T. J., D'Andrea, S. D., and Pierce, J. R.: Processes controlling the annual cycle of Arctic aerosol number and size distributions, Atmos. Chem. Phys., 16, 3665-3682, https://doi.org/10.5194/acp16-3665-2016, 2016.

Dacey, J. W. and Blough, N. V.: Hydroxide decomposition of dimethylsulfoniopropionate to form dimethylsulfide, Geophys. Res. Lett., 14, 1246-1249, 1987.

Delille, B., Jourdain, B., Borges, A. V., Tison, J. L., and Delille, D.: Biogas $\left(\mathrm{CO}_{2}, \mathrm{O}_{2}\right.$, dimethylsulfide) dynamics in spring Antarctic fast ice, Limnol. Oceanogr., 52, 1367-1379, 2007.

del Valle, D. A., Kieber, D. J., and Kiene, R. P.: Depth-dependent fate of biologically-consumed dimethylsulfide in the Sargasso Sea, Mar. Chem., 103, 197-208, 2007.

del Valle, D. A. D., Kieber, D. J., Toole, D. A., Brinkley, J., and Kiene, R. P.: Biological consumption of dimethylsulfide (DMS) and its importance in DMS dynamics in the Ross Sea, Antarctica, Limnol. Oceanogr., 54, 785-798, 2009.

DiTullio, G. R. and Smith Jr., W. O.: Relationship between dimethylsulfide and phytoplankton pigment concentrations in the Ross Sea, Antarctica, Deep-Sea Res. Pt. I, 42, 873-892, 1995.

Ehn, J. K., Mundy, C. J., Barber, D. G., Hop, H., Rossnagel, A., and Stewart, J.: Impact of horizontal spreading on light propagation in melt pond covered seasonal sea ice in the Canadian Arctic, J. Geophys. Res., 116, C00G02, https://doi.org/10.1029/2010JC006908, 2011.

Eicken, H.: Salinity profiles of Antarctic sea ice: Field data and model results, J. Geophys. Res., 97, 15545-15557, 1992.

Eicken, H., Krouse, H. R., Kadko, D., and Perovich, D. K., Tracer studies of pathways and rates of meltwater transport through arctic summer sea ice, J. Geophys. Res., 107, 8046, https://doi.org/10.1029/2000JC000583, 2002. 
Eicken, H., Grenfell, T. C., Perovich, D. K., Richter-Menge, J. A., and Frey, K.: Hydraulic controls of summer Arctic pack ice albedo, J. Geophys. Res.-Oceans., 109, C08007, https://doi.org/10.1029/2003JC001989, 2004.

Elliott, A., Mundy, C. J., Gosselin, M., Poulin, M., Campbell, K., and Wang, F.: Spring production of mycosporine-like amino acids and other UV-absorbing compounds in sea ice-associated algae communities in the Canadian Arctic, Mar. Ecol.-Prog. Ser., 541, 91-104, https://doi.org/10.3354/meps11540, 2015.

Fetterer, F. and Untersteiner, N.: Observations of melt ponds on Arctic sea ice, J. Geophys. Res.-Oceans, 103, 24821-24835, https://doi.org/10.1029/98JC02034, 1998.

Fuse, H., Takimura, O., Kamimura, K., Murakami, K., Yamaoka, Y., and Murooka, Y.: Transformation of dimethyl sulfide and related compounds by cultures and cell extracts of marine phytoplankton, Biosci. Biotech. Bioch., 59, 1773-1775, 1995.

Galindo, V., Levasseur, M., Mundy, C. J., Gosselin, M., Tremblay, J.-E., Scarratt, M., Gratton, Y., Papakiriakou, T., Poulin, M., and Lizotte, M.: Biological and physical processes influencing sea ice, under-ice algae, and dimethylsulfoniopropionate during spring in the Canadian Arctic Archipelago, J. Geophys. Res.-Oceans, 119, 3746-3766, https://doi.org/10.1002/2013JC009497, 2014.

Galindo, V., Levasseur, M., Scarratt, M., Mundy, C. J., Gosselin, M., Kiene, R. P., Gourdal, M., and Lizotte, M.: Under-ice microbial dimethylsulfoniopropionate metabolism during the melt period in the Canadian Arctic Archipelago, Mar. Ecol.-Prog. Ser., 524, 39-53, https://doi.org/10.3354/meps11144, 2015.

Gasol, J. M. and Del Giorgio, P. A.: Using flow cytometry for counting natural planktonic bacteria and understanding the structure of planktonic bacterial communities, Sci. Mar., 64, 197-224, 2000.

Ghiglione, J. F., Galand, P. E., Pommier, T., Pedrós-Alió, C., Maas, E. W., Bakker, K., Bertilson, S., Kirchman, D. L., Lovejoy, C., Yager, P. L. and Murray A. E.: Pole-to-pole biogeography of surface and deep marine bacterial communities, P. Natl. Acad. Sci. USA, 109, 17633-17638, 2012.

Giamarelou, M., Eleftheriadis, K., Nyeki, S., Tunved, P., Torseth, K., and Biskos, G.: Indirect evidence of the composition of nucleation mode atmospheric particles in the high Arctic, J. Geophys. Res.-Atmos., 121, 965-975, 2016.

González, J. M., Kiene, R. P., and Moran, M. A.: Transformation of Sulfur Compounds by an Abundant Lineage of Marine Bacteria in the $\alpha$-Subclass of the ClassProteobacteria, Appl. Environ. Microbiol., 65, 3810-3819, 1999.

Gourdal, M., Lizotte, M., and Levasseur, M.: Dimethylsulfide dynamics in first-year sea ice melt ponds in the Canadian Arctic Archipelago, available at: http://www.polardata.ca (last access: May 2018), last modification October 2017.

Gow, A. J., Ackley, S. F., Weeks, W. F., and Govoni, J. W.: Physical and structural characteristics of Antarctic sea ice, Ann. Glaciol., 3, 113-117, 1982.

Gow, A. J., Ackley, S. F., Buck, K. R., and Golden, K. M.: Physical and structural characteristics of Weddell Sea pack ice, Tech. Rep. 87-14, CRREL Cold Reg. Res. Eng. Lab., Hanover, N.H, 1987.

Gradinger, R. R., Meiners, K., Plumley, G., Zhang, Q., and Bluhm, B. A.: Abundance and composition of the sea-ice meiofauna in off-shore pack ice of the Beaufort Gyre in summer 2002 and 2003, Polar Biol., 28, 171-181, https://doi.org/10.1007/s00300004-0674-5, 2005.
Green, T. K. and Hatton, A. D.: The CLAW hypothesis: a new perspective on the role of biogenic sulphur in the regulation of global climate, Oceanogr. Mar. Biol., 52, 315-336, 2014.

Gunson, J. R., Spall, S. A., Anderson, T. R., Jones, A., Totterdell, I. J., and Woodage, M. J.: Climate sensitivity to ocean dimethylsulphide emissions, Geophys. Res. Lett., 33, L07701, https://doi.org/10.1029/2005GL024982, 2006.

Haas, C., Thomas, D. N., and Bareiss, J.: Surface properties and processes of perennial Antarctic sea ice in summer, J. Glaciol., 47, 613-625, 2001.

Hatton, A. D., Darroch, L., and Malin, G.: The role of dimethylsulphoxide in the marine biogeochemical cycle of dimethylsulphide, Oceanogr. Mar. Biol., 42, 29-56, 2004.

Hatton, A. D., Shenoy, D. M., Hart, M. C., Mogg, A., and Green, D. H.: Metabolism of DMSP, DMS and DMSO by the cultivable bacterial community associated with the DMSP-producing dinoflagellate Scrippsiella trochoidea, Biogeochemistry, 110, 131146, https://doi.org/10.1007/s10533-012-9702-7, 2012.

Holm-Hansen, O., Lorenzen, C. J., Holmes, R. W., and Strickland, J. D.: Fluorometric determination of chlorophyll ICES, J. Mar. Sci., 30, 3-15, 1965.

Hunke, E. C., Notz, D., Turner, A. K., and Vancoppenolle, M.: The multiphase physics of sea ice: a review for model developers, The Cryosphere, 5, 989-1009, https://doi.org/10.5194/tc-5-9892011, 2011.

Jardon, F. P., Vivier, F., Vancoppenolle, M., Lourenço, A., Bouruet-Aubertot, P., and Cuypers, Y.: Full-depth desalination of warm sea ice, J. Geophys. Res.-Oceans., 118, 435-447, https://doi.org/10.1029/2012JC007962, 2013.

Jung, J., Min, J. O., Yang, E. J., Lee, S. H., and Kang, S. H.: Nutrients in melt ponds and snows on Arctic sea ice during 2014 sea ice camp, The 21st International Symposium on Polar Sciences, 19-20 May 2015, KOPRI, Incheon., 2015.

Karsten, U., Kück, K., Vogt, C., and Kirst, G. O. (Eds.): Dimethylsulfoniopropionate production in phototrophic organisms and its physiological functions as a cryoprotectant, in: Biological and environmental chemistry of DMSP and related sulfonium compounds, Springer, New York, USA, 1996.

Keller, M. D., Bellows, W. K., and Guillard, R. R: Dimethyl sulfide production in marine phytoplankton: the importance of species composition and cell size, Biol. Oceanogr, 6, 375-382, 1989.

Kieber, D. J., Jiao, J., Kiene, R. P., and Bates, T. S.: Impact of dimethylsulfide photochemistry on methyl sulfur cycling in the equatorial Pacific Ocean, J. Geophys. Res., 101, 3715-3722, https://doi.org/10.1029/95JC03624, 1996.

Kiene, R. P. and Slezak, D.: Low dissolved DMSP concentrations in seawater revealed by small-volume gravity filtration and dialysis sampling, Limnol. Oceanogr.-Meth., 4, 80-95, 2006.

Kiene, R. P., Linn, L. J., and Bruton, J. A.: New and important roles for DMSP in marine microbial communities, J. Sea Res., 43, 209-224, 2000.

Kirst, G. O., Thiel, C., Wolff, H., Nothnagel, J., Wanzek, M., and Ulmke, R.: Dimethylsulfoniopropionate (DMSP) in icealgae and its possible biological role, Mar. Chem., 35, 381-388, https://doi.org/10.1016/S0304-4203(09)90030-5, 1991.

Korhonen, H., Carslaw, K. S., Forster, P. M., Mikkonen, S., Gordon, N. D., and Kokkola, H.: Aerosol climate feedback due to decadal increases in Southern Hemisphere wind speeds, Geophys. Res. Lett., 37, L02805, https://doi.org/10.1029/2009GL041320, 2010. 
Kwok, R., Cunningham, G. F., Wensnahan, M., Rigor, I., Zwally, H. J., and Yi, D.: Thinning and volume loss of the Arctic Ocean sea ice cover: 2003-2008: J. Geophys. Res.-Oceans, 114, C07005, https://doi.org/10.1029/2009JC005312, 2009.

Lana, A., Bell, T. G., Simó, R., Vallina, S. M., Ballabrera-Poy, J., Kettle, A. J., Dachs, J., Bopp, L., Saltzman, E. S., Stefels, J., Johnson, J. E., and Liss, P. S.: An updated climatology of surface dimethlysulfide concentrations and emission fluxes in the global ocean, Global Biogeochem. Cy., 25, GB1004, https://doi.org/10.1029/2010GB003850, 2011.

Lebaron, P., Servais, P., Agogué, H., Courties, C., and Joux, F.: Does the high nucleic acid content of individual bacterial cells allow us to discriminate between active cells and inactive cells in aquatic systems?, Appl. Environ. Microbiol., 67, 1775-1782, 2001.

Leck, C. and Bågander, L. E.: Determination of reduced sulfur compounds in aqueous solutions using gas chromatographyflame photometric detection, Anal. Chem., 60, 1680-1683, https://doi.org/10.1021/ac00168a011, 1988.

Leck, C. and Persson, C.: The central Arctic Ocean as a source of dimethyl sulfide: seasonal variability in relation to biological activity, Tellus B, 48, 156-177, 1996.

Lee, P. A. and De Mora, S. J.: Intracellular dimethylsulfoxide (DMSO) in unicellular marine algae: speculations on its origin and possible biological role, J. Phycol., 35, 8-18, 1999.

Lee, P. A., De Mora, S. J., Gosselin, M., Levasseur, M., Bouillon, R. C., Nozais, C., and Michel, C.: Particulate dimethylsulfoxide in Arctic sea-ice algal communities: The cryoprotectant hypothesis revisited, J. Phycol., 37, 488-499, 2001.

Lee, S. H., Stockwell, D. A., Joo, H.-M., Son, Y. B., Kang, C.K., and Whitledge, T. E.: Phytoplankton production from melting ponds on Arctic sea ice, J. Geophys. Res., 117, C04030, https://doi.org/10.1029/2011JC007717, 2012.

Legendre, L., Ackley, S. F., Dieckmann, G. S., Gulliksen, B., Horner, R., Hoshiai, T., Melnikov, I. A., Reeburgh, W. S., Spindler, M., and Sullivan, C. W.: Ecology of sea ice biota, Polar Biol., 12, 429-444, 1992.

Leppäranta, M. and Manninen, T.: The brine and gas content of sea ice with attention to low salinities and high temperatures, Internal Rep., 1-14, Finn. Inst. of Mar. Res., Helsinki, 1988.

Levasseur, M.: Impact of Arctic meltdown on the microbial cycling of sulphur, Nat. Geosci., 6, 691-700, 2013.

Levasseur, M., Gosselin, M., and Michaud, S.: A new source of dimethylsulfide (DMS) for the arctic atmosphere: ice diatoms, Mar. Biol., 121, 381-387, 1994.

Lizotte, M., Levasseur, M., Michaud, S., Scarratt, M. G., Merzouk, A., Gosselin, M., and Kiene, R. P.: Macroscale patterns of the biological cycling of dimethylsulfoniopropionate (DMSP) and dimethylsulfide (DMS) in the Northwest Atlantic, Biogeochemistry, 110, 183-200, https://doi.org/10.1007/s10533-011-9698-4, 2012.

Locarnini, S. J. P., Turner, S. M., and Liss, P. S.: The distribution of dimethylsulfide, DMS, and dimethylsulfoniopropionate, DMSP, in waters off the Western Coast of Ireland, Cont, Shelf Res., 18, 1455-1473, 1998.

Luce, M., Levasseur, M., Scarratt, M. G., Michaud, S., Royer, S. J., Kiene, R., Lovejoy, C., Gosselin, M., Poulin, M., Gratton, Y., and Lizotte, M.: Distribution and microbial metabolism of dimethylsulfoniopropionate and dimethylsulfide during the 2007
Arctic ice minimum, J. Geophys. Res.-Oceans, 116, C00G06, https://doi.org/10.1029/2010JC006914, 2011.

Lund, J. W. G., Kipling, C., and Le Cren, E. D.: The inverted microscope method of estimating algal numbers and the statistical basis of estimations by counting, Hydrobiologia, 11, 143-170, 1958.

Lüthje, M., Feltham, D. L., Taylor, P. D., and Worster, M. G.: Modeling the summertime evolution of seaice melt ponds, J. Geophys. Res.-Oceans, 111, C02001, https://doi.org/10.1029/2004JC002818, 2006.

Lyon, B. R., Bennett-Mintz, J. M., Lee, P. A., Janech, M. G., and DiTullio, G. R.: Role of dimethylsulfoniopropionate as an osmoprotectant following gradual salinity shifts in the sea-ice diatom Fragilariopsis cylindrus, Environ. Chem., 13, 181-194, 2016.

Malin, G., Turner, S., Liss, P., Holligan, P., and Harbour, D.: Dimethylsulphide and dimethylsulphoniopropionate in the Northeast Atlantic during the summer coccolithophore bloom, Deep-Sea Res. Pt. I, 40, 1487-1508, https://doi.org/10.1016/0967-0637(93)90125-M, 1993.

Marie, D., Simon, N., and Vaulot, D. (Eds.): Phytoplankton cell counting by flow cytometry. Andersen R., Algal culturing techniques, Academic Press, London, UK, 2005.

Massom, R. A., Stammerjohn, S. E., Smith, R. C., Pook, M. J., Iannuzzi, R. A., Adams, N., Martinson, D. G., Vernet, M., Fraser, W. R., Quetin, L. B., Ross, R. M., Massom, Y., and Krouse, R. H.: Extreme anomalous atmospheric circulation in the West Antarctic Peninsula region in austral spring and summer 2001/02, and its profound impact on sea ice and biota, J. Climate, 19, 35443571, 2006.

Matrai, P. A. and Vernet, M.: Dynamics of the vernal bloom in the marginal ice zone of the Barents Sea: Dimethyl sulfide and dimethylsulfoniopropionate budgets, J. Geophys. Res.-Oceans, 102, 22965-22979, 1997.

McArdle, N. C. and Liss, P. S.: Isotopes and atmospheric sulphur, Atmos. Environ., 29, 2553-2556, https://doi.org/10.1016/13522310(95)00188-5, 1995.

Miller, L. A., Fripiat, F., Else, B. G. T., Bowman, J. S., Brown, K. A., Collins, R. E., Ewert, M, Fransson, A., Gosselin, M., Lannuzel, D., Meiners, K. M., Michel, C., Nishioka, J., Nomura, D., Papadimitriou, S., Russell, L. M., Sørensen, L. L., Thomas, D. N., Tison, J.-L., van Leeuwe, M. A., Vancoppenolle, M., Wolff, E. W., and Zhou J.: Methods for biogeochemical studies of sea ice: The state of the art, caveats, and recommendations, Elem. Sci. Anth., 3, 53, https://doi.org/10.12952/journal.elementa.000038, 2015.

Mungall, E. L., Croft, B., Lizotte, M., Thomas, J. L., Murphy, J. G., Levasseur, M., Martin, R. V., Wentzell, J. J. B., Liggio, J., and Abbatt, J. P. D.: Dimethyl sulfide in the summertime Arctic atmosphere: measurements and source sensitivity simulations, Atmos. Chem. Phys., 16, 6665-6680, https://doi.org/10.5194/acp16-6665-2016, 2016.

Niki, T., Kunugi, M., and Otsuki, A.: DMSP-lyase activity in five marine phytoplankton species: its potential importance in DMS production, Mar. Biol., 136, 759-764, 2000.

Nomura, D., Koga, S., Kasamatsu, N., Shinagawa, H., Simizu, D., Wada, M., and Fukuchi, M.: Direct measurements of DMS flux from Antarctic fast sea ice to the atmosphere by a chamber technique, J. Geophys. Res.-Oceans, 117, 2012. 
Pandey, S. K. and Kim, K. H.: A review of methods for the determination of reduced sulfur compounds (RSCs) in air, Environ. Sci. Technol., 43, 3020-3029, https://doi.org/10.1021/es803272f, 2009.

Parsons, T. R., Maita, Y., and Lalli, C. M.: A manual of biological and chemical methods for seawater analysis, Publ. Pergamon Press, Oxford, 1984.

Perovich, D. K., Richter-Menge, J. A., Jones, K. F., Light, B., Elder, B. C., Polashenski, C., Laroche, D., Markus, T., and Lindsay, R.: Arctic sea-ice melt in 2008 and the role of solar heating, Ann. Glaciol., 52, 355-359, https://doi.org/10.3189/172756411795931714, 2011.

Petrich, C. and Eicken H.: Growth, structure and properties of sea ice, in: Sea Ice, edited by: Thomas, D. N. and Dieckmann, G. S., 23-77, Blackwell, Oxford, UK, 2010.

Pio, C. A., Castro, L. M., Cerqueira, M. A., Santos, I. M., Belchior, F., and Salgueiro, M. L.: Source assessment of particulate air pollutants measured at the southwest European coast, Atmos. Environ., 30, 3309-3320, https://doi.org/10.1016/13522310(96)00058-1, 1996

Polashenski, C., Perovich, D., and Courville, Z.: The mechanisms of sea ice melt pond formation and evolution, J. Geophys. Res.Oceans, 117, C01001, https://doi.org/10.1029/2011JC007231, 2012.

Polashenski, C., Golden, K. M., Perovich, D. K., Skyllingstad, E., Arnsten, A., Stwertka, C., and Wright, N.: Percolation blockage: A process that enables melt pond formation on first year Arctic sea ice, J. Geophys. Res.-Oceans, 122, 413-440, 2017.

Quinn, P. K. and Bates, T. S.: The case against climate regulation via oceanic phytoplankton sulphur emissions, Nature, 480, 5156, https://doi.org/10.1038/nature10580, 2011.

R Core Team: A language and environment for statistical computing, R Foundation for Statistical Computing, Vienna, Austria, available at: https://www.R-project.org/ (last access: November 2017), 2016.

Rempillo, O., Seguin, A. M., Norman, A.-L., Scarratt, M., Michaud, S., Chang, R., Sjostedt, S., Abbatt, J., Else, B., Papakyriakou, T., Sharma, S., Grasby, S., and Levasseur, M.: Dimethyl sulfide air-sea fluxes and biogenic sulfur as a source of new aerosols in the Arctic fall, J. Geophys. Res., 116, D00S04, https://doi.org/10.1029/2011JD016336, 2011.

Rösel, A., Kaleschke, L., and Birnbaum, G.: Melt ponds on Arctic sea ice determined from MODIS satellite data using an artificial neural network, The Cryosphere, 6, 431-446, https://doi.org/10.5194/tc-6-431-2012, 2012.

Royer, S. J., Galí, M., Mahajan, A. S., Ross, O. N., Pérez, G. L., Saltzman, E. S., and Simó, R.: A high-resolution time-depth view of dimethylsulphide cycling in the surface sea, Sci. Rep.-UK., 6, 32325, https://doi.org/10.1038/srep32325, 2016.

Scarratt, M. G., Levasseur, M., Schultes, S., Michaud, S., Cantin, G., Vezina, A., and De Mora, S. J.: Production and consumption of dimethylsulfide (DMS) in North Atlantic waters, Mar. Ecol.Prog. Ser., 204, 13-26, https://doi.org/10.3354/meps204013, 2000.

Sharma, S., Barrie, L. A., Plummer, D., McConnell, J. C., Brickell, P. C., Levasseur, M., Gosselin, M., and Bates, T. S.: Flux estimation of oceanic dimethyl sulfide around North America, J. Geophys. Res., 104, 21327-21342, 1999.
Simó, R.: Production of atmospheric sulfur by oceanic plankton: biogeochemical, ecological and evolutionary links, Trends Ecol. Evol., 16, 287-294, 2001.

Simó, R. and Pedrós-Alió, C.: Role of vertical mixing in controlling the oceanic production of dimethyl sulphide, Nature, 402, 396399, 1999a.

Simó, R. and Pedrós-Alió, C.: Short-term variability in the open ocean cycle of dimethylsulfide, Global Biogeochem. Cy., 13, 1173-1181, 1999b.

Simó, R., Pedrós-Alió, C., Malin, G., and Grimalt, J. O.: Biological turnover of DMS, DMSP and DMSO in contrasting open-sea waters, Mar. Ecol.-Prog. Ser., 203, 1-11, 2000.

Skyllingstad, E. D. and Paulson, C. A.: A numerical study of melt ponds, J. Geophys. Res., 112, C08015, https://doi.org/10.1029/2006JC003729, 2007.

Sokal, R. R. and Rohlf, F. J. (Eds): Biometry: the principles and practice of statistics in biological research, WH Freeman and Co., New York, USA, 1995.

Sørensen, H. L., Thamdrup, B., Jeppesen, E., Rysgaard, S., and Glud, R. N.: Nutrient availability limits biological production in Arctic sea ice melt ponds, Polar Biol., 40, 1593-1606, https://doi.org/10.1007/s00300-017-2082-7, 2017.

Spiese, C. E., Kieber, D. J., Nomura, C. T., and Kiene, R. P.: Reduction of dimethylsulfoxide to dimethylsulfide by marine phytoplankton, Limnol. Oceanogr., 54, 560-570, 2009.

Stefels, J.: Physiological aspects of the production and conversion of DMSP in marine algae and higher plants, J. Sea Res., 43, 183 197, 2000.

Stefels, J., Steinke, M., Turner, S., Malin, G., and Belviso, S.: Environmental constraints on the production and removal of the climatically active gas dimethylsulphide (DMS) and implications for ecosystem modelling, Biogeochemistry, 83, 245-275, https://doi.org/10.1007/s10533-007-9091-5, 2007.

Stohl, A.: Characteristics of atmospheric transport into the Arctic troposphere, J. Geophys. Res.-Atmos., 111, D11306, https://doi.org/10.1029/2005JD006888, 2006.

Stroeve, J. C., Markus, T., Boisvert, L., Miller, J., and Barrett, A.: Changes in Arctic melt season and implications for sea ice loss, Geophys. Res. Lett., 41, 1216-1225, https://doi.org/10.1002/2013GL058951, 2014.

Sunda, W. K. D. J., Kieber, D. J., Kiene, R. P., and Huntsman, S.: An antioxidant function for DMSP and DMS in marine algae, Nature, 418, 317-320, 2002.

Thomas, M. A., Suntharalingam, P., Pozzoli, L., Rast, S., Devasthale, A., Kloster, S., Feichter, J., and Lenton, T. M.: Quantification of DMS aerosol-cloud-climate interactions using the ECHAM5-HAMMOZ model in a current climate scenario, Atmos. Chem. Phys., 10, 7425-7438, https://doi.org/10.5194/acp10-7425-2010, 2010.

Throndsen, J., Hasle, G. R., and Tangen, K. (Eds.): Phytoplankton of Norwegian coastal waters, Almater Forlag AS, Oslo, Norway, 2003.

Tison, J. L., Brabant, F., Dumont, I., and Stefels, J.: High-resolution dimethyl sulfide and dimethylsulfoniopropionate time series profiles in decaying summer first-year sea ice at Ice Station Polarstern, western Weddell Sea, Antarctica, J. Geophys. Res.Biogeo., 115, G04044, https://doi.org/10.1029/2010JG001427, 2010. 
Tomas, C. R. and Hasle, G. R. (Eds.): Identifying marine phytoplankton, Academic Press, New York, USA, 1997.

Trevena, A. J. and Jones, G. B.: Dimethylsulphide and dimethylsulphoniopropionate in Antarctic sea ice and their release during sea ice melting, Mar. Chem., 98, 210-222, 2006.

Trevena, A. J., Jones, G. B., Wright, S. W., and Van den Enden, R. L.: Profiles of dimethylsulphoniopropionate (DMSP), algal pigments, nutrients, and salinity in the fast ice of Prydz Bay, Antarctica, J. Geophys. Res.-Oceans, 108, 3145, https://doi.org/10.1029/2002JC001369, 2003.

Turner, S. M., Nightingale, P. D., Broadgate, W., and Liss, P. S.: The distribution of dimethyl sulphide and dimethylsulphoniopropionate in Antarctic waters and sea ice, Deep-Sea Res. Pt. II, 42, 1059-1080, 1995.

Twomey, S.: Pollution and the planetary albedo, Atmos. Environ, 8, 1251-1256, https://doi.org/10.1016/0004-6981(74)90004-3, 1974.

van Bergeijk, S. A. and Stal, L. J.: The role of oxygenic phototrophic microorganisms in production and conversion of dimethylsulfoniopropioniate and dimethylsulfide in microbial mats, In Biological and Environmental Chemistry of DMSP and Related Sulfonium Compounds, 369-379, Springer, Boston, MA, 1996.

Vancoppenolle, M., Bitz, C. M., and Fichefet, T., Summer landfast sea ice desalination at point barrow: Model and observations, J. Geophys. Res., 112, C04022, https://doi.org/10.1029/2006JC003493, 2007.

Vancoppenolle, M., Goosse, H., De Montety, A., Fichefet, T., Tremblay, B., and Tison, J. L.: Modeling brine and nutrient dynamics in Antarctic sea ice: The case of dissolved silica, J. Geophys. Res.-Oceans, 115, C02005, https://doi.org/10.1029/2009JC00536, 2010.

Vila-Costa, M., Simó, R., Harada, H., Gasol, J. M., Slezak, D., and Kiene, R. P.: Dimethylsulfoniopropionate uptake by marine phytoplankton, Science, 314, 652-654, https://doi.org/10.1126/science.1131043, 2006.

Vila-Costa, M., Simó, R., Alonso-Sáez, L., and Pedrós-Alió, C.: Number and phylogenetic affiliation of bacteria assimilating dimethylsulfoniopropionate and leucine in the ice-covered coastal Arctic Ocean, J. Marine Syst., 74, 957-963, 2008.
Vogt, C., Rabenstein, A., Rethmeier, J., and Fischer, U.: Dimethyl sulphoxide reduction with reduced sulphur compounds as electron donors by anoxygenic phototrophic bacteria, Microbiology, 143, 767-773, 1997.

Welsh, D. T.: Ecological significance of compatible solute accumulation by micro-organisms: from single cells to global climate, FEMS Microbiol. Rev., 24, 263-290, 2000.

Weeks, W. F. and Ackley, S. F.: The growth, structure, and properties of sea ice, in: The geophysics of sea ice, 9-164, Springer, Boston, MA, 1986.

Willis, M. D., Burkart, J., Thomas, J. L., Köllner, F., Schneider, J., Bozem, H., Hoor, P. M., Aliabadi, A. A., Schulz, H., Herber, A. B., Leaitch, W. R., and Abbatt, J. P. D.: Growth of nucleation mode particles in the summertime Arctic: a case study, Atmos. Chem. Phys., 16, 7663-7679, https://doi.org/10.5194/acp16-7663-2016, 2016.

Wolfe, G. V., Levasseur, M., Cantin, G., and Michaud, S.: Microbial consumption and production of dimethyl sulfide (DMS) in the Labrador Sea, Aquat. Microb. Ecol., 18, 197-205, https://doi.org/10.3354/ame018197, 1999.

Woodhouse, M. T., Carslaw, K. S., Mann, G. W., Vallina, S. M., Vogt, M., Halloran, P. R., and Boucher, O.: Low sensitivity of cloud condensation nuclei to changes in the sea-air flux of dimethyl-sulphide, Atmos. Chem. Phys., 10, 7545-7559, https://doi.org/10.5194/acp-10-7545-2010, 2010.

Zemmelink, H. J., Gieskes, W. W. C., Klaassen, W., De Groot, H. W., De Baar, H. J. W., Dacey, J. W. H., Hintsa, E. J., and McGillis, W. R.: Simultaneous use of relaxed eddy accumulation and gradient flux techniques for the measurement of sea-to-air exchange of dimethyl sulphide, Atmos. Environ., 36, 5709-5717, https://doi.org/10.1016/S1352-2310(02)00577-0, 2002.

Zemmelink, H. J., Dacey, J. W., Houghton, L., Hintsa, E. J., and Liss, P. S.: Dimethylsulfide emissions over the multi-year ice of the western Weddell Sea, Geophys. Res. Lett., 35, L06603, https://doi.org/10.1029/2007GL031847, 2008. 